\title{
TEM Examination of Advanced Alloys Irradiated in ATR
}

\author{
Jian Gan \\ Bruce A. Hilton
}

September 2007

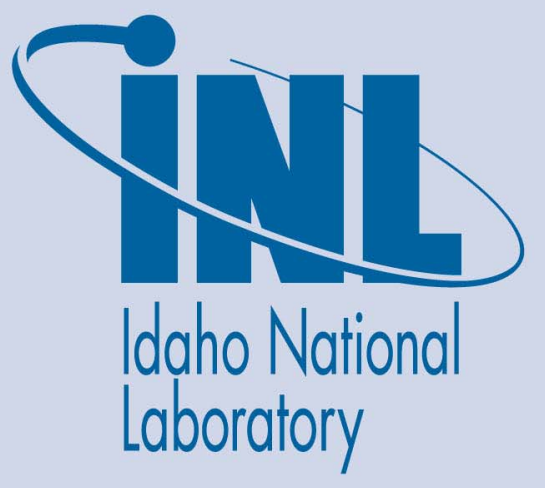

The INL is a U.S. Department of Energy National Laboratory operated by Battelle Energy Alliance 
INL/EXT-07-13306

\title{
TEM Examination of Advanced Alloys Irradiated in ATR
}

\author{
Jian Gan \\ Bruce A. Hilton \\ GNEP PIE Program Manager \\ Bruce A. Hilton
}

September 2007

\author{
Idaho National Laboratory \\ Nuclear Fuels and Materials Division \\ Idaho Falls, Idaho 83415
}

Prepared for the

U.S. Department of Energy

Office of Nuclear Energy

Under DOE Idaho Operations Office

Contract DE-AC07-05ID14517 


\section{DISCLAIMER}

This information was prepared as an account of work sponsored by an agency of the U.S. Government. Neither the U.S. Government nor any agency thereof, nor any of their employees, makes any warranty, expressed or implied, or assumes any legal liability or responsibility for the accuracy, completeness, or usefulness, of any information, apparatus, product, or process disclosed, or represents that its use would not infringe privately owned rights. References herein to any specific commercial product, process, or service by trade name, trade mark, manufacturer, or otherwise, does not necessarily constitute or imply its endorsement, recommendation, or favoring by the U.S. Government or any agency thereof. The views and opinions of authors expressed herein do not necessarily state or reflect those of the U.S. Government or any agency thereof. 


\section{CONTENTS}

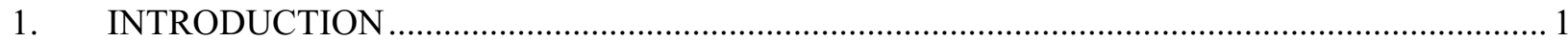

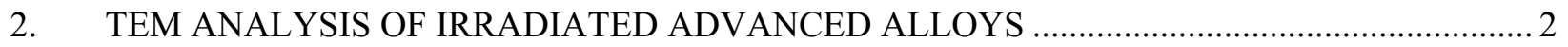

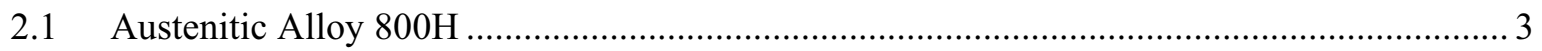

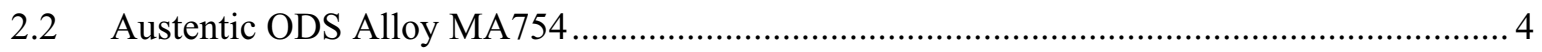

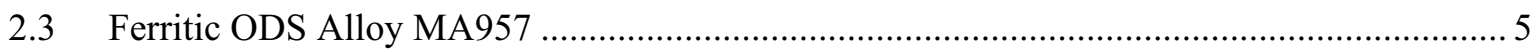

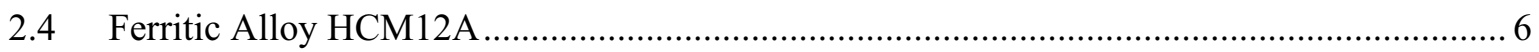

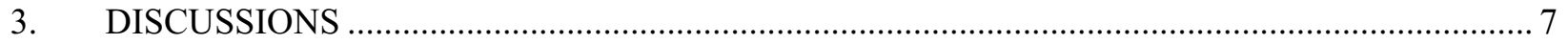

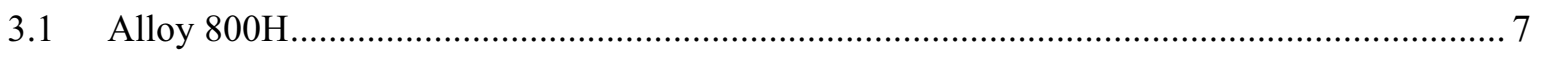

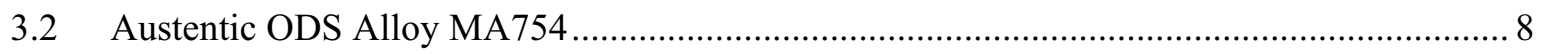

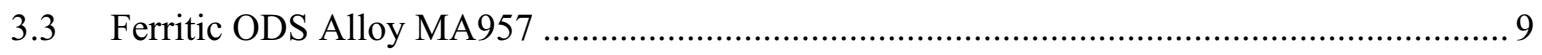

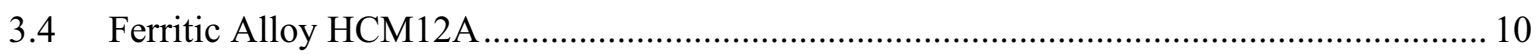

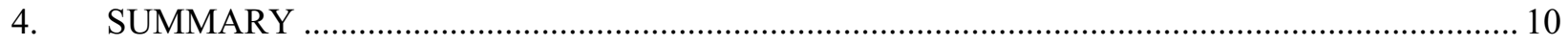

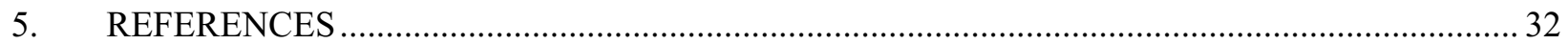

\section{FIGURES}

Figure 1. Unirradiated microstructure of alloy $800 \mathrm{H}$ (imaged with $\mathrm{g}=200$ diffraction) reveals large and scattered Ti rich particles (top), dislocations in low magnification (middle), and high magnification (bottom).

Figure 2. Bright field images showing defect features in the alloy $800 \mathrm{H}$ irradiated with neutrons at $500^{\circ} \mathrm{C}$ to $1.3 \mathrm{dpa}$. (a) distribution of $\mathrm{M}_{23} \mathrm{C}_{6}$ precipitates with small ones in the matrix and the large ones at the grain boundaries, (b) dislocations and the circular $\gamma^{\prime}$ precipitates in the weak contrast, and (c) the high magnification view of the faceted feature of $\mathrm{M}_{23} \mathrm{C}_{6}$ precipitates and micro voids $(<5 \mathrm{~nm})$ in the white contrast.

Figure 3. Comparison of $<112>$ zone diffraction in alloy $800 \mathrm{H}$ between the unirradiated (left) and the neutron-irradiated at $500^{\circ} \mathrm{C}$ to $1.3 \mathrm{dpa}$ (right). Two types of coherent precipitates are found in the irradiated alloy, and the circles mark the weak spots due to $\gamma$ ' precipitates.

Figure 4. EDS plots of alloy $800 \mathrm{H}$ for the matrix (top), the large Ti-rich particles existed in both the unirradiated and the irradiated condition (middle), and the $\mathrm{M}_{23} \mathrm{C}_{6}$ precipitates in the irradiated condition (bottom). EDS measurement of irradiation-induced $\gamma^{\prime}$ precipitates is not quantifiable due to their small size.

Figure 5. Weak beam dark field images showing the circular $\gamma^{\prime}$ precipitates (top) and the thin plate features (bottom) in the alloy $800 \mathrm{H}$ irradiated with neutrons at $500^{\circ} \mathrm{C}$ to $1.3 \mathrm{dpa}$. 15

Figure 6. Size distribution of micro voids in the alloy $800 \mathrm{H}$ irradiated at $500^{\circ} \mathrm{C}$ to $1.3 \mathrm{dpa}$. Note that the corresponding swelling and hardening are expected to be negligible.... 16 
Figure 7. Selected area diffractions of zone $<112>$ (left) and zone $<111>$ (right) for alloy $800 \mathrm{H}$ irradiated with neutrons at $800^{\circ} \mathrm{C}$ to $1.5 \mathrm{dpa}$. There are two types of coherent precipitates found in the irradiated alloy; the circles mark the weak spots due to $\gamma$ ' precipitates, while the rest of the weak spots are due to $\mathrm{M}_{23} \mathrm{C}_{6}$ precipitates.

Figure 8. Bright field images showing comparison of irradiation-induced $\mathrm{M}_{23} \mathrm{C}_{6}$ precipitates in the alloy $800 \mathrm{H}$ irradiated with neutrons at $500^{\circ} \mathrm{C}$ to $1.3 \mathrm{dpa}$ (top) and $800^{\circ} \mathrm{C}$ to $1.5 \mathrm{dpa}$ (bottom). Note that the precipitates at the grain boundaries are larger for the irradiation at $800^{\circ} \mathrm{C}$.

Figure 9. Comparison of size distributions for the irradiation-induced $\mathrm{M}_{23} \mathrm{C}_{6}$ precipitates in the alloy $800 \mathrm{H}$ irradiated with neutrons at $500^{\circ} \mathrm{C}$ to $1.3 \mathrm{dpa}$ (top) and $800^{\circ} \mathrm{C}$ to $1.5 \mathrm{dpa}$ (bottom). There is no significant change on $\mathrm{M}_{23} \mathrm{C}_{6}$ precipitates between the two irradiation conditions.

Figure 10. Weak beam dark field images comparing irradiation-induced $\gamma^{\prime}$ precipitates in the alloy $800 \mathrm{H}$ irradiated with neutrons at $500^{\circ} \mathrm{C}$ to $1.3 \mathrm{dpa}$ (top) and $800^{\circ} \mathrm{C}$ to $1.5 \mathrm{dpa}$ (bottom).

Figure 11. Comparison of size distributions for the irradiation-induced $\gamma^{\prime}$ precipitates in the alloy $800 \mathrm{H}$ irradiated with neutrons at $500^{\circ} \mathrm{C}$ to $1.3 \mathrm{dpa}$ (top) and $800^{\circ} \mathrm{C}$ to $1.5 \mathrm{dpa}$ (bottom). There is a significant change on the size and number density of $\gamma^{\prime}$ precipitates.

Figure 12. Yttrium oxide particles in alloy MA754 for the unirradiated (left) and the irradiated with neutrons at $500^{\circ} \mathrm{C}$ to $1.2 \mathrm{dpa}$ (right). The images on the top show dislocation contrast using $\mathrm{g}=200$, and the images on the bottom show irradiation effect on yttrium oxides. Dislocation density in the irradiated MA754 is significantly lower, while the irradiation effect on yttrium oxide is not significant.

Figure 13. Size distribution of yttrium oxide particles in alloy MA754 for the unirradiated (top) and the irradiated with neutrons at $500^{\circ} \mathrm{C}$ to $1.2 \mathrm{dpa}$ (bottom). There is no significant change in average size, size distribution, and number density of the oxide particles.

Figure 14. Various precipitates found in both the unirradiated and the irradiated alloy MA754 (at $500^{\circ} \mathrm{C}$ to $1.2 \mathrm{dpa}$ ). The plots show the EDS measurement for the major precipitates identified in the alloy.

Figure 15. Low magnification images of microstructural features in MA957 for the unirradiated (top), the irradiated at $500^{\circ} \mathrm{C}$ to $1.2 \mathrm{dpa}$ (middle), and at $800^{\circ} \mathrm{C}$ to $1.4 \mathrm{dpa}$ (bottom). No noticeable changes in the general microstructure.

Figure 16. High magnification images of dislocations in MA957 for the unirradiated (top), the irradiated at $500^{\circ} \mathrm{C}$ to $1.2 \mathrm{dpa}$ (middle), and at $800^{\circ} \mathrm{C}$ to $1.4 \mathrm{dpa}$ (bottom). No noticeable changes in the dislocation configuration.

Figure 17. High magnification images of yttrium oxide particles (large circular features and small spots) in MA957 for the unirradiated (top), the irradiated at $500^{\circ} \mathrm{C}$ to $1.2 \mathrm{dpa}$ (middle), and at $800^{\circ} \mathrm{C}$ to $1.4 \mathrm{dpa}$ (bottom).

Figure 18. Size distribution of yttrium oxide particles in MA957 for the unirradiated (top), the irradiated at $500^{\circ} \mathrm{C}$ to $1.2 \mathrm{dpa}$ (middle), and at $800^{\circ} \mathrm{C}$ to $1.4 \mathrm{dpa}$ (bottom). Irradiation resulted in smaller average sizes and higher densities of the oxide particles.

Figure 19. Low magnification images of general microstructural features in HCM12A for the unirradiated (top) and the irradiated at $500^{\circ} \mathrm{C}$ to $1.1 \mathrm{dpa}$ (bottom). 
Figure 20. High magnification image showing dislocations $(\mathrm{g}=1,-1,0)$, precipitates (top) and black dots in $\mathrm{HCM} 12 \mathrm{~A}$ irradiated at $500^{\circ} \mathrm{C}$ to $1.1 \mathrm{dpa}$ (bottom). Few scattered dislocation loops are visible in the image on the top.

Figure 21. Voids are found in one area $\left(\sim 10 \mu \mathrm{m}^{2}\right)$ of the $\mathrm{HCM} 12 \mathrm{~A}$ alloy irradiated at $500^{\circ} \mathrm{C}$ to $1.1 \mathrm{dpa}$.

Figure 22. Summary of measurement for voids found in a particular area $\left(\sim 10 \mu \mathrm{m}^{2}\right)$ of the $\mathrm{HCM} 12 \mathrm{~A}$ alloy irradiated with neutrons at $500^{\circ} \mathrm{C}$ to $1.1 \mathrm{dpa}$.

\section{TABLES}

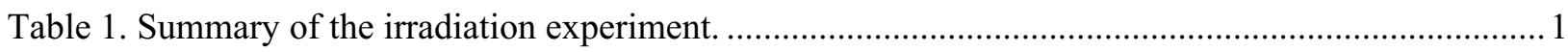

Table 2. Chemical compositions of the alloys investigated................................................................2

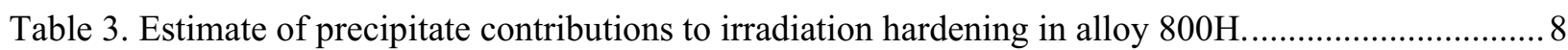




\section{TEM Examination of Advanced Alloys Irradiated in ATR}

\section{INTRODUCTION}

Successful development of materials is critical to the deployment of advanced nuclear power systems. Irradiation studies of candidate materials play a vital role for better understanding materials performance under various irradiation environments of advanced system designs. In many cases, new classes of materials have to be investigated to meet the requirements of these advanced systems. For applications in the temperature range of $500-800^{\circ} \mathrm{C}$ which is relevant to the fast neutron spectrum burner reactors for the Global Nuclear Energy Partnership (GNEP) program, oxide dispersion strengthened (ODS) and ferritic-martensitic steels (e.g., MA957 and others) are candidates for advanced cladding materials. In the low temperature regions of the core $\left(<600^{\circ} \mathrm{C}\right)$, alloy $800 \mathrm{H}, \mathrm{HCM} 12 \mathrm{~A}$ (also called T-122) and HT-9 have been considered.

The work summarized in this report focuses on microstructural characterization of four advanced alloys: nickel-based MA754 (ODS) alloys, iron-based HCM12A and MA957 (ODS) ferritic alloys, and high $\mathrm{Ni}$ austenitic alloy $800 \mathrm{H}$, irradiated with neutrons to relatively low dose $(1.1 \sim 1.5$ displacements per atom [dpa]) at $500^{\circ} \mathrm{C}$ and $800^{\circ} \mathrm{C}$ in the Advanced Test Reactor (ATR) at the Idaho National Laboratory (INL). The irradiation conditions are listed in Table 1 . The variation in the irradiation dose is due to the axial position of the test specimens and the flux variation in the axial direction. The temperature control was based on gamma heating of the specimens and heat transfer through an argon and helium gas mixture in the specimen capsule with the target temperatures of $500^{\circ} \mathrm{C}$ and $800^{\circ} \mathrm{C}$. No in-line temperature measurement was conducted, so temperature was determined by analysis. Alloy composition is listed in Table 2 .

Table 1. Summary of the irradiation experiment.

\begin{tabular}{|c|c|c|c|}
\hline Alloys & $\begin{array}{c}\text { Irradiation } \\
\text { Temperature } \\
\left(\mathrm{C}^{\circ}\right)\end{array}$ & $\begin{array}{c}\text { Days of } \\
\text { Irradiation } \\
(\text { EFPD })\end{array}$ & $\begin{array}{c}\text { Neutron fluence }(\mathrm{E}>1 \mathrm{MeV})\left(\text { neutrons } / \mathrm{cm}^{2}\right) \\
(\mathrm{dose} \text { in dpa })\end{array}$ \\
\hline HCM12A & 500 & 110.8 & $7.8 \times 10^{20},(1.1 \mathrm{dpa})$ \\
\hline MA754 & 500 & 110.8 & $8.2 \times 10^{20},(1.2 \mathrm{dpa})$ \\
\hline MA957 & 500 & 110.8 & $8.5 \times 10^{20},(1.2 \mathrm{dpa})$ \\
\hline $800 \mathrm{H}$ & 500 & 110.8 & $8.8 \times 10^{20},(1.3 \mathrm{dpa})$ \\
\hline MA957 & 800 & 110.8 & $9.9 \times 10^{20},(1.4 \mathrm{dpa})$ \\
\hline $800 \mathrm{H}$ & 800 & 110.8 & $10.2 \times 10^{20},(1.5 \mathrm{dpa})$ \\
\hline & & & Use $7 \times 10^{20} \mathrm{n} / \mathrm{cm}^{2}=1.0 \mathrm{dpa}$ for dpa calc.(Ref.) \\
\hline
\end{tabular}


Table 2. Chemical compositions of the alloys investigated.

\begin{tabular}{|c|c|c|c|c|c|c|c|c|c|c|c|}
\hline Alloys & $\begin{array}{l}\text { Density } \\
\mathrm{g} / \mathrm{cm}^{3}\end{array}$ & $\mathrm{Si}$ & $\mathrm{Ti}$ & $\mathrm{Al}$ & $\mathrm{C}$ & $\mathrm{N}$ & $\mathrm{Fe}$ & $\mathrm{Ni}$ & $\mathrm{Cr}$ & W & Other element \\
\hline HCM12A & 8.03 & 0.26 & -- & -- & 0.11 & 0.07 & Bal. & -- & 11.28 & 1.83 & $\begin{array}{c}1.03 \mathrm{Cu}, 0.67 \mathrm{Mn} \\
0.39 \mathrm{Ni}, 0.007 \mathrm{~B}\end{array}$ \\
\hline MA754 & 8.3 & -- & 0.5 & 0.3 & 0.05 & -- & 1.00 & 78 & 20 & -- & $0.6 \mathrm{Y}_{2} \mathrm{O}_{3}$ \\
\hline MA957 & 7.8 & 0.04 & 1.05 & 0.10 & -- & -- & 84.13 & 0.13 & 13.87 & -- & $\begin{array}{c}0.30 \mathrm{Mo}, 0.08 \mathrm{Mn} \\
0.25 \mathrm{Y}_{2} \mathrm{O}_{3} \\
\sim 0.17 \mathrm{O}\end{array}$ \\
\hline $800 \mathrm{H}$ & 7.94 & 0.13 & 0.57 & 0.50 & 0.069 & -- & 45.26 & 31.59 & 20.42 & -- & $0.76 \mathrm{Mn}$ \\
\hline
\end{tabular}

After irradiation, the capsules of disc samples ( $3 \mathrm{~mm}$ diameter and $\sim 200 \mu \mathrm{m}$ thickness) were transferred to the Hot Fuel Examination Facility (HFEF) at the Materials and Fuels Complex (MFC) for transmission electron microscopy (TEM) disc retrieval. The irradiated TEM discs were then transferred to the Electron Microscopy Laboratory (EML) at MFC for TEM sample preparation and microstructural characterization. For austenitic alloys (800H and MA754), the $3.0 \mathrm{~mm}$ diameter TEM discs were ground down to $\sim 150 \mu \mathrm{m}$. For ferritic stainless steels (MA957 and HCM12A), a smaller disc format (2.3 mm diameter and $\sim 70 \mu \mathrm{m}$ thickness) was used to minimize the magnetic interference with electron beams during TEM analysis. TEM discs were electro-chemical jet polished to perforation using $5 \%$ perchloric acid in methanol at a temperature of approximately $-40^{\circ} \mathrm{C}$. A JEOL 2010 transmission electron microscope with $\mathrm{LaB}_{6}$ filament and a Gatan UltraScan1000 digital camera was used for characterization.

\section{TEM ANALYSIS OF IRRADIATED ADVANCED ALLOYS}

The microstructural analysis consists of characterizing the radiation-induced microstuctural features such as cavities, loops, precipitates, and dislocations. In addition, for ODS alloys, the changes in oxide particle size distribution and number density are estimated. The effect of radiation on oxide particle stability is evaluated. Results of the microstructural analysis from the unirradiated alloys of the same batch are used for comparison with the results of the irradiated alloys. In the following sections, the analysis for each irradiated alloy, 800H, MA754, MA957 and HCM12A, will be presented first and then compared with its unirradiated condition. Due to the saturation of Energy Dispersive Spectrometer (EDS) detector from the radiation of the irradiated TEM specimens, composition analysis for precipitates is only available for the sample with relatively low radioactivity. The comparison of the results from this work to the others work will be made afterwards. 


\subsection{Austenitic Alloy $800 \mathrm{H}$}

The proposed advanced nuclear energy systems are aimed to make revolutionary improvements in economics, safety and reliability, and sustainability. To achieve these goals, the reactors will be operated at higher temperatures and to higher accumulated radiation damage than current light water reactors. Metallic alloy components will experience unprecedented microstructural and mechanical property evolution as they progress to higher doses. Of the candidate alloy systems that could be considered for high temperature application, alloy $800 \mathrm{H}$ is expected to play an important role as a structural material since it is code certified for temperatures up to $760^{\circ} \mathrm{C}$ for use in nuclear systems. ${ }^{1}$ Alloy $800 \mathrm{H}$ has a composition of $31.6 \mathrm{wt} . \%$ nickel and $20.4 \mathrm{wt} \%$ chromium. It is expected to exhibit low swelling based on its high Ni content (>30 wt.\%), which has been shown in austenitic steels to improve resistance to swelling under neutron irradiation at $400^{\circ} \mathrm{C}$ to a dose of $18.5 \mathrm{dpa}^{2}$ The alloy also is expected to have good corrosion resistance based on its high Cr content. It is worth mentioning that, among the 4 alloys investigated, both alloy $800 \mathrm{H}$ and MA 754 are not the primary candidates for GNEP fuel cladding, although these alloys are capable of operating at high temperature. This is partly due to the high Ni content in these alloys that produces helium through transmutation reaction: ${ }^{58} \mathrm{Ni}(\mathrm{n}, \gamma)^{59} \mathrm{Ni}(\mathrm{n}, \alpha){ }^{56} \mathrm{Fe}$.

The alloy $800 \mathrm{H}$ used in this work is a commercial grade received in the plate form from Rolled Alloys, Inc. in USA. The material was used in the as-received condition with the final heat treatment at $1,177^{\circ} \mathrm{C}$ for 2.25 hours followed by a water quench. The unirradiated microstructure of alloy $800 \mathrm{H}$ is shown in Figure 1. There were a few large and scattered Ti rich particles $(\sim 0.5 \mu \mathrm{m}$ with $\sim 94$ at $\% \mathrm{Ti}$ and $\sim 3$ at $\% \mathrm{Cr}$ ) in the matrix. The alloy has a dislocation density of approximately $4 \times 10^{13} \mathrm{~m}^{-2}$, which is relatively high for the condition of heat-treated at $1,177^{\circ} \mathrm{C}$ for 2.25 hours.

For the samples irradiated at $500^{\circ} \mathrm{C}$ to $1.3 \mathrm{dpa}$ in the ATR, the irradiation resulted in significant changes in the microstructure due to the irradiation-induced precipitation (see Figure 2). Two types of precipitates formed, and both crystals have a fixed orientation relationship to the matrix of $800 \mathrm{H}$. One is identified as $\mathrm{M}_{23} \mathrm{C}_{6}$, the commonly observed Cr-rich carbide with a fcc crystal structure, uniformly distributed through the grains with many of them showing facet features. The $\mathrm{M}_{23} \mathrm{C}_{6}$ precipitates populated at the grain boundaries are larger in size and irregular in shape as shown in Figure 2(a). The insert of the diffraction pattern in Figure 2(c) indicates that the faceted surfaces of $\mathrm{M}_{23} \mathrm{C}_{6}$ carbides have $\{111\}$ type planes with most carbides elongated close to the $<220>$ direction.

The second type of irradiation-induced precipitates, shown as weak contrast, circular features in Figure 2(b), are barely visible in the matrix under bright field image condition. While the dislocation arrangement remains similar between the unirradiated and the irradiated condition, a low density of micro voids $(<5 \mathrm{~nm})$ are present in the irradiated sample with a few voids attached to the $\mathrm{M}_{23} \mathrm{C}_{6}$ carbides, shown in Figure 2(c). Both the bright field and the rel-rod weak beam dark field images did not reveal any faulted loops in the $800 \mathrm{H}$ irradiated at $500^{\circ} \mathrm{C}$ to $1.3 \mathrm{dpa}$. A comparison of the selected-area diffraction (SAD) from zone [112] is shown in Figure 3. While the diffraction spots from $\mathrm{M}_{23} \mathrm{C}_{6}$ are clearly visible with a $1 / 3$ spacing to the $800 \mathrm{H}$ matrix spots, the circle-marked weak spots due to the $\gamma$ ' precipitates are quite faint. Figure 4 shows EDS spectra of the $800 \mathrm{H}$ matrix, large Ti rich particles in both unirradiated and irradiated conditions, and the $\mathrm{M}_{23} \mathrm{C}_{6} \mathrm{Cr}$ rich precipitates in the irradiated condition. The EDS spectrum for $\gamma$ ' could not be characterized due to their small size and the limitations of the electron beam probe size and detector. The composition of $\gamma^{\prime}$ is expected to be $\mathrm{Ni}_{3}(\mathrm{Ti}, \mathrm{Al})$ with a fcc crystal structure. ${ }^{3}$ The $\gamma^{\prime}$ precipitates are much better revealed under the weak beam dark field imaging condition using one of the weak spots from $\gamma^{\prime}$; see Figure 5 (top). The irradiated $800 \mathrm{H}$ also contains scattered thin platelets, shown in Figure 5 (bottom). 
The measurement of micro voids is summarized in Figure 6 . Average void diameter, number density, and the corresponding volume swelling are estimated to be $3.6 \mathrm{~nm}, 2.5 \times 10^{14} \mathrm{~cm}^{-3}$ and $7.7 \times 10^{-4} \%$, respectively. The effect of voids on mechanical property and dimensional stability for alloy $800 \mathrm{H}$ irradiated at $500^{\circ} \mathrm{C}$ to $1.3 \mathrm{dpa}$ is negligible.

For the alloy $800 \mathrm{H}$ irradiated at $800^{\circ} \mathrm{C}$ to $1.5 \mathrm{dpa}$, the SAD diffractions from zone [112] and [111] are shown in Figure 7. The weak spots due to $\gamma^{\prime}$ precipitates are marked with small circles. The diffraction from zone [112] on the left is similar to that of Figure 3. The diffraction of zone [111] shows an enhanced spot intensity from $\gamma^{\prime}$ precipitates. The effect of irradiation temperature on the $\mathrm{M}_{23} \mathrm{C}_{6}$ precipitates is demonstrated in Figure 8. While Cr carbides in the matrix remain similar in size and distribution, the large $\mathrm{Cr}$ carbides at grain boundaries are bigger for irradiation at $800^{\circ} \mathrm{C}$ than that of $500^{\circ} \mathrm{C}$. The lower number of $\mathrm{Cr}$ carbides shown in the $800^{\circ} \mathrm{C}$ irradiation temperature is due to the thinner foil thickness compared to the area imaged for $500^{\circ} \mathrm{C}$ condition. The measurements on $\mathrm{M}_{23} \mathrm{C}_{6} \mathrm{Cr}$ carbides in the matrix for both irradiation temperatures are summarized in Figure 9. There is no noticeable change in carbide size, size distribution, and number density between the two irradiation temperatures. The sizes and densities of $\mathrm{M}_{23} \mathrm{C}_{6} \mathrm{Cr}$ carbides in alloy $800 \mathrm{H}$ for the $500^{\circ} \mathrm{C}$ and $800^{\circ} \mathrm{C}$ irradiations are estimated to be $34 \mathrm{~nm}$ and $35 \mathrm{~nm}, 5.5 \times 10^{14} \mathrm{~cm}^{-3}$ and $5.8 \times 10^{14} \mathrm{~cm}^{-3}$, respectively.

Weak beam dark field images of $\gamma^{\prime}$ precipitates in the alloy irradiated at $800^{\circ} \mathrm{C}$ is shown in Figure 10 with comparison to the irradiation condition at $500^{\circ} \mathrm{C}$. There is a dramatic change due to temperature effect on the development of radiation-induced $\gamma^{\prime}$ precipitates in alloy $800 \mathrm{H}$. The measurements of the $\gamma^{\prime}$ precipitates are summarized in Figure 11. The size distribution is significantly different between the two irradiation temperatures. The comparison of $\gamma^{\prime}$ precipitates in alloy $800 \mathrm{H}$ irradiated at $800^{\circ} \mathrm{C} \mathrm{vs.} 500^{\circ} \mathrm{C}$ shows a higher number density $\left(1.3 \times 10^{16} \mathrm{~cm}^{-3}\right.$ vs. $\left.3.4 \times 10^{14} \mathrm{~cm}^{-3}\right)$, smaller size $(12.0 \mathrm{~nm}$ vs. $34.7 \mathrm{~nm})$, and higher volume fraction $(1.4 \%$ vs. $0.9 \%)$. The impact of $\gamma^{\prime}$ precipitates on the mechanical property of alloy $800 \mathrm{H}$ is expected to be larger for the irradiation at $800^{\circ} \mathrm{C}$.

\subsection{Austentic ODS Alloy MA754}

The austenitic ODS alloy MA754 used in this work was received from Special Metals Corporation in the plate form in the recrystallized condition. It is an ODS Ni-based $(78 \% \mathrm{Ni}) \mathrm{Ni}-\mathrm{Cr}$ super-alloy for high temperature application with excellent high temperature strength and resistance to creep and corrosion. It has a much better oxidation resistance than alloy $800 \mathrm{H}$. According to the alloy specification and technical notes, it is an attractive material to be used for gas turbine engine components, furnace fixtures and fasteners due to its high melting point $\left(1,400^{\circ} \mathrm{C}\right)$ and microstructural stability. ${ }^{4}$ The stability of oxide dispersions under neutron irradiation is the subject of this work.

The weak beam dark field image using rel-rod imaging technique did not reveal any faulted dislocation loops in the irradiated MA754. No voids are found in this material. Figure 12 shows the dislocation arrangement (top) and oxide particles (bottom) for the unirradiated (left) and the irradiated (right) $\left(500^{\circ} \mathrm{C}, 1.2 \mathrm{dpa}\right) \mathrm{MA} 754$. The images on the top were recorded with diffraction of $\mathrm{g}=\{200\}$ to show the dislocation contrast in fcc metal. The dislocation density is quite low in the unirradiated condition. For the sample irradiated at $500^{\circ} \mathrm{C}$ to $1.2 \mathrm{dpa}$, the dislocation density is further reduced. The bottom micrographs were imaged without dislocation contrast to show oxide particles. There is no significant change on the oxide particles.

The size distribution, mean particle size, particle volume and number density of oxide particles are summarized in Figure 13. The size distribution remains similar between the unirradiated and the irradiated conditions, with the average particle size of $15 \mathrm{~nm}$ vs. $16 \mathrm{~nm}$, and number density of $4 \times 10^{15} \mathrm{~cm}^{-3}$ vs. $3 \times 10^{15} \mathrm{~cm}^{-3}$, respectively. Since oxide dispersion particles in MA754 play an important role on its mechanical properties, irradiation at $500^{\circ} \mathrm{C}$ to $1.2 \mathrm{dpa}$ is expected to have little impact on its mechanical properties. 
There are precipitates other than yttrium oxide particles also present in both the unirradiated and the irradiated conditions. Figure 14 shows an area containing the major types of precipitates in MA754. The representative EDS spectra for those precipitates marked in the picture are included in the figure. There are four types of precipitates identified: oxide dispersion particles (compound of $\mathrm{Y}, \mathrm{Al}$ and $\mathrm{O}$ ), Ti rich particles, $\mathrm{Cr}$ rich particles, and $\mathrm{Al}$ rich particles (likely $\mathrm{Al}$ oxides). The effect of irradiation on these particles other than yttrium oxide particles could not be quantified due to their low densities and small sizes. Based on their low densities, the impact of these particles on the mechanical properties of MA754 is expected to be insignificant in comparison to the yttrium oxide dispersion particles.

\subsection{Ferritic ODS Alloy MA957}

MA957 is a ferritic ODS alloy developed for fast reactor cladding application. The mechanically alloyed powders are consolidated by hot extrusion in an evacuated steel can to form wrought bar. The cladding tubes can be made from the bars after a series of steps. The details on the alloy development can be found in reference ${ }^{5}$. The scale of alloy development never reached mass production for commercial use. Major drawbacks of MA957 is its anisotropic grain and subgrain structure and mechanical properties. Another potential limitation in advanced nuclear systems is due to the large amount of Al in the alloy that leads to the formation of alumina stringers believed to be detrimental to the material strength.

Recognizing these shortcomings, it was included in this study as a representative ODS alloy developed specifically for nuclear reactor application in the USA.

Alloy MA957 has a messy and complex microstructure with submicron grains, high density of dislocations, subgrain cell structures, and various types of precipitates in addition to yttrium oxide particles. The focus in this work is to investigate the stability of yttrium oxides under neutron irradiation. Composition analysis with EDS for the unirradiated sample revealed both Al rich precipitates and Ti rich precipitates at low densities. EDS measurements for the irradiated samples were not available due to the high background counts from the sample radioactivity. The low magnification TEM images of the general microstructural features are shown in Figure 15 for the conditions of unirradiated (top), irradiated at $500^{\circ} \mathrm{C}$ to $1.2 \mathrm{dpa}$ (middle), and irradiated at $800^{\circ} \mathrm{C}$ to $1.4 \mathrm{dpa}$ (bottom). The general microstructural features for all three conditions are dominated by the subgrain cell structures and dislocations. No significant changes can be identified. Since all the TEM disc samples are made with its surface normal aligned to the rolling direction of the bar, all the grains or subgrains appear equal-axial.

High magnification TEM images showing dislocation arrangement among the three conditions are shown in Figure 16. The dislocation configurations appear to remain similar for the unirradiated and the irradiated at $500^{\circ} \mathrm{C}$ and $800^{\circ} \mathrm{C}$ to $1.2 \sim 1.4 \mathrm{dpa}$. No dislocation loops were found in the irradiated samples. Radiation-induced voids were not present. There is no noticeable annealing effect on the dislocations arrangement for the $800^{\circ} \mathrm{C}$ irradiation. Yttrium oxide dispersion particles are believed to play an important role in stabilizing the dislocation configuration in the irradiated MA957. 
Radiation effects on yttrium oxide particles are shown in Figure 17. For the unirradiated condition, the distribution of yttrium oxide particles, particularly the large particles, is relatively non-uniform. Two images are shown at the top for the unirradiated condition with one from an area mainly consisting of small spots $(\sim 2 \mathrm{~nm})$ and the other one from an area containing clusters of large particles. The irradiation at $500^{\circ} \mathrm{C}$ to $1.2 \mathrm{dpa}$ seemingly eliminated the clusters of large yttrium particles with more pronounced development of the small particles. The irradiation at 800 to 1.4 dpa reveals only few scattered large yttrium particles with matrix mostly decorated with small yttrium particles. From the EDS measurement, most of the large particles shown in Figure 17 contain $\mathrm{Y}, \mathrm{Ti}, \mathrm{Al}$, and $\mathrm{O}$. The measurements of size distribution, average size, and number densities for yttrium oxide dispersion particles for the three conditions are summarized in Figure 18. The change in particle size distribution clearly illustrates the reduction of large yttrium particles and promotion of the small particles for irradiation at $500^{\circ} \mathrm{C}$ and $800^{\circ} \mathrm{C}$ to $1.3 \mathrm{dpa}$. The sizes of yttrium oxide particles for the unirradiated, irradiated at $500^{\circ} \mathrm{C}$ and at $800^{\circ} \mathrm{C}$ are $10 \mathrm{~nm}, 7 \mathrm{~nm}$ and $6 \mathrm{~nm}$, respectively. The corresponding number densities of the oxide dispersion particles are $1.8 \times 10^{15} \mathrm{~cm}^{-3}, 3.1 \times 10^{15} \mathrm{~cm}^{-3}$, and $5.6 \times 10^{15} \mathrm{~cm}^{-3}$, respectively. The trend appears that irradiation at $500^{\circ} \mathrm{C} / 1.2 \mathrm{dpa}$ and $800^{\circ} \mathrm{C} / 1.4 \mathrm{dpa}$ tends to slightly shrink the particle size and increase the particle density in MA957.

\subsection{Ferritic Alloy HCM12A}

HCM12A is an advanced $12 \mathrm{Cr}$ ferritic alloy developed for high temperature application. It has been considered for application in core components in Generation IV nuclear energy system as well as for advanced cladding materials in the GNEP program due to its anticipated excellent resistance to corrosion and void swelling. Note that the $12 \mathrm{Cr}$ alloy HT9 was the most advanced cladding and duct material used in the fast reactors of the Fast Flux Test Facility (FFTF) and Experimental Breeder Reactor (EBR)-II. ${ }^{6}$ $\mathrm{HCM} 12 \mathrm{~A}$ is designed to operate at an upper temperature limit $\left(\sim 620^{\circ} \mathrm{C}\right)$ approximately $55^{\circ} \mathrm{C}$ higher than HT9. $^{7}$

HCM12A used in this work was obtained in plate form from Sumitomo Metal Industries, Kashima Steel Works in Japan. The alloy was normalized at $1,050^{\circ} \mathrm{C}$ followed by air-cooling and then tempered at $770^{\circ} \mathrm{C}$ followed by air-cooling. The average grain size of the prior austenite grains is $14 \pm 3 \mu \mathrm{m}$. The general microstructures for both the unirradiated and the irradiated HCM12A are shown in Figure 19. Most of the precipitates present are identified as $\mathrm{M}_{23} \mathrm{C}_{6}$ carbides. The population of carbides at grain boundaries in the irradiated $\left(500^{\circ}\right.$ and $\left.1.1 \mathrm{dpa}\right)$ sample is higher than the unirradiated condition. The overall microstructure for both conditions is dominated by the dense dislocations and carbides. A close-up look at the irradiated microstructure is shown in Figure 20. The image on the top shows the dislocation network and a few scattered dislocation loops along with precipitates, while the image at the bottom shows the spot feature uniformly distributed in the matrix. Since black dot damage is expected to occur only at relatively low irradiation temperature $\left(<300^{\circ} \mathrm{C}\right.$ for stainless steel $),{ }^{8}$ these spot features may have been introduced during TEM sample preparation by the radiation damage from room temperature ion milling or the initial stage of small precipitates.

Small voids were found with relatively high density in the irradiated HCM12A in only one area of approximately $\sim 10 \mu \mathrm{m}^{2}$; see Figure 21 . This represents less than $1 \%$ of the total thin area examined. It was a surprise, since voids are not expected in this material at $\sim 1 \mathrm{dpa}$. No voids are found in the other part of the irradiated sample. The chemical analysis and the crystal structure analysis for the area with voids revealed no noticeable difference to the rest of the sample. The cause of void development in this particular area is not clear. Both local chemical fluctuation and residual austenite grain in this particular area in the unirradiated sample may be responsible for the void development. Note that void swelling peaks around irradiation temperature of $550^{\circ} \mathrm{C}$ for the austenitic stainless steel. Void distribution and measurement of this $10 \mu \mathrm{m}^{2}$ area are summarized in Figure 22. The average void size, number density, and corresponding swelling are $2.7 \pm 0.9 \mathrm{~nm}, 4.3 \times 10^{16} \mathrm{~cm}^{-3}$ and $0.06 \%$, respectively. 


\section{DISCUSSIONS}

The results of the TEM microstructutal analysis for the four advanced alloys irradiated with neutrons in ATR at irradiation temperatures of $\sim 500^{\circ} \mathrm{C}$ and $\sim 800^{\circ} \mathrm{C}$ to doses of $1.1 \sim 1.4$ dpa have been presented in the previous sections. This section will discuss those results in comparison with the relevant irradiation work of others. Both neutron irradiation and ion irradiation will be included. The discussion will provide some insights into the feasibility of these alloys to be used for cladding or other core components.

\subsection{Alloy $800 \mathrm{H}$}

The dramatic change in the $800 \mathrm{H}$ microstructure irradiated to relatively low dose $(\sim 1 \mathrm{dpa})$ is expected to significantly degrade the alloy performance. Radiation hardening from precipitates is expected to be large even without faulted loops. Note that, at $500^{\circ} \mathrm{C}$ irradiation, large faulted loops are a signature feature of radiation damage in the microstructure of austenitic alloys. The lack of faulted loops at $500^{\circ} \mathrm{C}$ irradiation is likely due to the development of both types of precipitates $\left(\mathrm{M}_{23} \mathrm{C}_{6}\right.$ and $\left.\gamma^{\prime}\right)$. These precipitates serve as neutral sinks for point defects; therefore, the amount of interstitials available for nucleation and growth of faulted loops are significantly reduced. The accumulation of large Cr-rich $\mathrm{M}_{23} \mathrm{C}_{6}$ at grain boundaries from irradiation could alter the grain boundary chemistry by $\mathrm{Cr}$ depletion and weaken the grain boundaries. The impact of small voids at low density in the matrix should have no effect on the material performance at dose up to $1.3 \mathrm{dpa}$. The thin platelets shown in Figure 5 (image at bottom) are likely stacking faults. These features are narrower than typical stacking faults in $304 \mathrm{SS}$, possibly due to the higher Ni content in $800 \mathrm{H}$ associated with a higher stacking fault energy. The impact of these stacking faults on the mechanical properties of the irradiated $800 \mathrm{H}$ is expected to be less important due to their low density.

The Ni ion irradiation of $800 \mathrm{H}$ at $500^{\circ} \mathrm{C}$ to 5 dpa revealed faulted loops with size and density of $13 \mathrm{~nm}$ and $1.2 \times 10^{16} \mathrm{~cm}^{-3}$, respectively. ${ }^{9}$ No voids were found even for doses up to $50 \mathrm{dpa}$.

Radiation-induced precipitates were identified only in the 50 dpa condition with size and density of $6 \mathrm{~nm}$ and $9.1 \times 10^{15} \mathrm{~cm}^{-3}$, respectively. The chemical analysis for these small precipitates was not successful due to their small size. Considering the high damage rate in $\mathrm{Ni}$ ion irradiation, the $500^{\circ} \mathrm{C}$ irradiation temperature simulates the neutron irradiation condition around $350^{\circ} \mathrm{C}$. The lack of $\mathrm{M}_{23} \mathrm{C}_{6}$ and $\gamma^{\prime}$ in the $\mathrm{Ni}$ ion irradiated $800 \mathrm{H}$ is likely due to the effect of temperature shift. The lack of He production from transmutation of $\mathrm{Ni}$ in $\mathrm{Ni}$ ion irradiation may explain the absence of voids in the Ni ion irradiation study of alloy $800 \mathrm{H}$. The different irradiated microstructure of $800 \mathrm{H}$ observed in neutron-irradiated and $\mathrm{Ni}$ ion-irradiated at $500^{\circ} \mathrm{C}$ material indicates that the use of $\mathrm{Ni}$ ion irradiation to simulate neutron irradiation consider should consider the effects of the high damage rate on sample temperature and microstructure development.

Gelles, et al. conducted an irradiation study on a very similar alloy (Alloy 800 ) irradiated with neutrons in EBR-II at $425^{\circ} \mathrm{C}$ and $540^{\circ} \mathrm{C}$ to $\sim 100 \mathrm{dpa}$, and the alloy developed severe void swelling to $41 \%$ and $12 \%$, respectively. Small and finely distributed MC precipitates and large $\gamma$ ' precipitates were present. No $\mathrm{M}_{23} \mathrm{C}_{6}$ type precipitates were reported in the irradiated alloy 800 . The $\gamma^{\prime}$ precipitates after $540^{\circ} \mathrm{C}$ irradiation are much larger than after $425^{\circ} \mathrm{C}$ irradiation. The difference between Gelles' work and this work is mostly due to the large difference in dose in addition to the irradiation temperature difference. 
At $800^{\circ} \mathrm{C}$ irradiation, there is a strong temperature effect on the precipitates. The $\mathrm{Cr}$ carbide precipitates at grain boundaries are larger than that observed in the $500^{\circ} \mathrm{C}$ irradiation. The most noticeable change is $\gamma^{\prime}$ precipitates, with significantly smaller size and higher density at $800^{\circ} \mathrm{C}$ irradiation. At this irradiation temperature, both faulted loops and voids are not expected to be present. Nucleation of $\gamma$ ' precipitates is enhanced at $800^{\circ} \mathrm{C}$ irradiation. The smaller size is likely due to the limited amount of $\mathrm{Al}$ and Ti available for the growth of $\gamma^{\prime}$ in high density. The radiation hardening from both $\mathrm{M}_{23} \mathrm{C}_{6}$ and $\gamma^{\prime}$ can be estimated using the dispersion barrier hardening model for changes in yield strength: ${ }^{10}$

$$
\Delta \sigma_{y}=3.06 \alpha \mu b \sqrt{N \cdot d}
$$

where $\alpha$ is the barrier strength factor ( $\sim$ for precipitates), $\mu$ is the shear modulus, $b$ is the Burgers vector for network dislocation, $\mathrm{N}$ is the number density, and $\mathrm{d}$ is the size of precipitates. For austenitic alloys, $\mu=76 \mathrm{GPa}$ and $\mathrm{b}=2.55 \times 10^{-8} \mathrm{~cm}$. The calculated precipitate contribution to the radiation hardening is listed in Table 3. It is clear that the irradiation hardening due to $\gamma^{\prime}$ at $500^{\circ} \mathrm{C}$ irradiation is similar to that caused by carbides. For irradiation at $800^{\circ} \mathrm{C}$, radiation hardening significantly increases and is dominated by $\gamma^{\prime}$ precipitates. Radiation hardening is detrimental to the material performance in irradiation environment. The severe radiation hardening of alloy $800 \mathrm{H}$ at relatively low irradiation dose suggests that this material should not be used as cladding or other core components exposed to neutron irradiation in the service temperature of $500-800^{\circ} \mathrm{C}$.

Table 3. Estimate of precipitate contributions to irradiation hardening in alloy $800 \mathrm{H}$.

\begin{tabular}{|c|c|c|c|c|c|}
\hline $\begin{array}{c}\text { Precipitates } \\
\text { type }\end{array}$ & $\begin{array}{c}\text { Irradiation } \\
\text { temperature } \\
\left({ }^{\circ} \mathrm{C}\right)\end{array}$ & $\begin{array}{c}\text { Irradiation } \\
\text { dose } \\
(\mathrm{dpa})\end{array}$ & $\begin{array}{c}\text { Precipitate } \\
\text { density } \\
\left(10^{15} \mathrm{~cm}^{-3}\right)\end{array}$ & $\begin{array}{c}\text { Precipitate } \\
\text { size } \\
(\mathrm{nm})\end{array}$ & $\begin{array}{c}\text { Hardening } \\
\Delta \sigma_{\mathrm{y}} \\
(\mathrm{MPa})\end{array}$ \\
\hline$\gamma^{\prime}$ & 500 & 1.3 & 0.34 & 34 & 202 \\
\hline$\gamma^{\prime}$ & 800 & 1.5 & 13 & 12 & 741 \\
\hline Carbide & 500 & 1.3 & 0.55 & 34 & 256 \\
\hline Carbide & 800 & 1.5 & 0.58 & 35 & 267 \\
\hline
\end{tabular}

\subsection{Austentic ODS Alloy MA754}

There is a paucity of microstructural data in the open literature for neutron-irradiated MA754. The lack of research interest in this area for MA754 is probably due to it being a Ni-base alloy, which alloy class generally exhibits poor void swelling resistance under neutron irradiation due to helium production. Nickel transmutes to helium, and the helium production rate is proportional to the Ni content. ${ }^{11}$ The alloy used in this work was in the recrystallized condition with a very low dislocation density. The lack of voids and faulted loops in MA754 irradiated at $500^{\circ} \mathrm{C}$ to $1.2 \mathrm{dpa}$ in this work is possibly attributed to the oxide dispersion particles promoting point defect recombination at the interface of the dispersion particles and the matrix. Low dislocation density also makes void development more difficult due to the lack of biases sinks for preferential absorption of interstitials at dislocations. Irradiation to 1.2 dpa slightly increases the average particle size and decreases particle density; however, these small changes are statistically insignificant. The material performance is expected to be the same between the unirradiated and the irradiated at $500^{\circ} \mathrm{C}$ to $1.2 \mathrm{dpa}$. 
Shirashi et al. in their work reported that voids were nucleated preferably on the oxide-matrix interface for the helium pre-injected ( $\sim 300 \mathrm{appm})$ MA754 irradiated with protons at $450-600^{\circ} \mathrm{C}$ to $20 \mathrm{dpa} .{ }^{12}$ It was found that swelling increases with irradiation temperature to approximately $1 \%, 3 \%, 5 \%$, and $10 \%$ at $450,500,550$, and $600^{\circ} \mathrm{C}$, respectively. The anticipated swelling reduction by oxide dispersion particles was not observed in their work. It suggests that the oxide dispersion particles in austenitic ODS alloys are not effective in suppressing void swelling. The major differences between their work and this work are on the irradiation dose (20 dpa vs. $1.2 \mathrm{dpa})$ and irradiation type (proton with $\mathrm{He}$ pre-injection vs. neutron). It is anticipated that MA754 may develop void swelling at higher dose due to its high $\mathrm{Ni}$ content providing a source of helium production. The future work on the high dose irradiation of MA754 will be necessary to confirm this hypothesis.

\subsection{Ferritic ODS Alloy MA957}

The microstructure of ferritic ODS MA957 is very different than the austenitic ODS MA754. Dislocation density is very high and the grain size is very small in MA957. The stability of the dislocation microstructure in the irradiated MA957 is evident as shown in Figures 15-16. The lack of changes for irradiation at both $500^{\circ} \mathrm{C}$ and $800^{\circ} \mathrm{C}$ is likely due to the combined effects of the high density of dislocations, subgrain boundaries and oxide dispersion particles. A high density of oxide dispersion particles stabilizes the dislocation arrangement and subgrain boundaries even at irradiation temperature of $800^{\circ} \mathrm{C}$, which impedes thermal recovery and prohibits grain growth. Note that dislocation bias for bcc is lower than fec. The retention of a very high dislocation density maintains a strong sink for both interstitials and vacancies, which effectively limits the development of irradiation-induced defect microstructure. Other important facts for the bcc crystal include high self-diffusion, low helium generation rate $(<1 \% \mathrm{Ni})$ and high subgrain boundaries sink strength, making the alloy inherently more swelling resistant than fcc austenitic alloys. ${ }^{13}$

The irradiation at $500^{\circ} \mathrm{C}$ and $800^{\circ} \mathrm{C}$ to $1.2-1.4$ dpa did not significantly affect the oxide dispersion particles. There is no evidence of any coarsening of oxide particles; see Figure 17. In contrast to a coarsening effect on the oxide dispersion particles, the irradiation eliminated the clusters of large yttrium oxide particles and enhanced the number density of small oxide particles in the irradiated MA957 with average oxide particle sizes of $10 \mathrm{~nm}, 6.9 \mathrm{~nm}$ and $6.0 \mathrm{~nm}$ for the unirradiated, irradiated at $500^{\circ} \mathrm{C}$ to $1.2 \mathrm{dpa}$ and irradiated at $800^{\circ} \mathrm{C}$ to $1.4 \mathrm{dpa}$, respectively. This trend is consistent with the heavy ion irradiation study of a $9 \mathrm{Cr}$ ferritic ODS alloy. ${ }^{14}$ The small reduction in size and increase in number density for oxide dispersion particles are believed to be beneficial to the alloy performance under irradiation.

Gelles et al. reported that no microstructural evidence was found in MA957 for radiation damage after irradiation at $550^{\circ} \mathrm{C}$ to a dose of $8.0 \times 10^{22} \mathrm{n} / \mathrm{cm}^{2}(40 \mathrm{dpa})$ [5]. The mechanical tests performed by Gelles et al. showed no difference in yield strength between the unirradiated and the irradiated at $500^{\circ}$ and $700^{\circ} \mathrm{C}$ to $28.5 \mathrm{dpa}$. The irradiation at $750^{\circ} \mathrm{C}$ to 40 dpa revealed a microstructure similar to that of $550^{\circ} \mathrm{C}$ except the presence of clusters of small cavities within the large $\mathrm{TiO}_{2}$ precipitates. No quantitative measurement was conducted on the radiation stability of oxide dispersion particles. Their results, regardless the large difference in irradiation doses to this work, are consistent with the results in this work with irradiation at $500^{\circ} \mathrm{C}$ and $800^{\circ} \mathrm{C}$ to 1.2 and $1.4 \mathrm{dpa}$, respectively. The large difference in the irradiated microstructure between the high dose irradiations of MA754 (proton, $20 \mathrm{dpa}$ ) and MA957 (neutron, $40 \mathrm{dpa}$ ) reported in the open literature suggests that the role of oxide dispersion particles on swelling resistance is less important than the crystal structure (fcc vs bcc), the original dislocation arrangement, and the grain structure (low dislocation density vs. high dislocation and subgrain densities). The importance of the oxide dispersion particles on materials performance is due to its effect on high temperature mechanical strength. The role of oxide particles on the radiation resistance is believed to be secondary through the mechanism of stabilizing the dislocation and subgrain microstructure. 


\subsection{Ferritic Alloy HCM12A}

Alloy HCM12A has an initial microstructure typical of ferritic stainless steels with precipitates in different size and shapes distributed in the matrix and at the grain boundaries. These precipitates are mostly identified as $\mathrm{M}_{23} \mathrm{C}_{6}$ carbides. The only visible change from irradiation at $500^{\circ} \mathrm{C}$ to $1.1 \mathrm{dpa}$ is the slightly increased precipitate population at the grain boundaries and the presence of a few scattered dislocation loops. The presence of voids at this relatively low dose in one area of the sample is quite surprising; see Figure 21. These voids are still in the incubation stage since the average diameter of mature voids should be much larger at the irradiation temperature of $500^{\circ} \mathrm{C}$. Since the rest of the TEM sample analyzed is free of voids and the area fraction showing voids is very small $(<1 \%)$, micro voids should not be considered a representative defect feature in $\mathrm{HCM} 12 \mathrm{~A}$ irradiated at $500^{\circ} \mathrm{C}$ to $1.1 \mathrm{dpa}$.

The Ni ion irradiation of the same alloy at $500^{\circ} \mathrm{C}$ to 5 and 50 dpa revealed no changes in microstructure at $5 \mathrm{dpa}$ and few scattered dislocation loops in areas with a high density of dislocations at $50 \mathrm{dpa} .{ }^{15}$ The dominant microstructural features for both unirradiated and the Ni ion-irradiated HCM12A are dense dislocations with $\mathrm{M}_{23} \mathrm{C}_{6}$ precipitates. No voids were found even at $50 \mathrm{dpa}$. The proton irradiation of the same alloy at $400^{\circ} \mathrm{C}$ to 10 dpa revealed voids $\left(6.2 \mathrm{~nm}\right.$ size, $9.4 \times 10^{14} \mathrm{~cm}^{-3}$ density, $0.015 \%$ swelling), small precipitates $\left(5.7 \mathrm{~nm}\right.$ size, $3.9 \times 10^{15} \mathrm{~cm}^{-3}$ density), and dislocation loops (34 $\mathrm{nm}$ size, $3.2 \times 10^{14} \mathrm{~cm}^{-3}$ density, $\mathrm{a}_{0}<100>$ type). The composition and crystal structure information of the small precipitates could not be obtained due to their small size and detector limit. For comparison with previous neutron irradiation data, HT-9 $(12 \mathrm{Cr}-1 \mathrm{MoVW})$ is considered a similar ferritic alloy to HCM12A with excellent swelling resistance. After irradiation in FFTF to 35 and 205 dpa at $420^{\circ} \mathrm{C}$, the void swelling in HT-9 estimated from TEM data was only $0.007 \%$ and $0.09 \%$, respectively. ${ }^{16,17} \mathrm{HCM} 12 \mathrm{~A}$ is expected to exhibit similar swelling resistance to HT-9 with an improvement on its upper limit of application temperature. The lack of microstructural change in this work is expected, since the irradiation dose of 1.1 dpa is too low to show any noticeable change.

\section{SUMMARY}

The results of TEM analysis of the four advanced alloys, 800H, MA754, MA957 and HCM12A, have been presented. These materials are all developed for high temperature applications. The microstructural analysis of these alloys irradiated in ATR at 500 and $800^{\circ} \mathrm{C}$ to doses of 1.1-1.5 dpa lead to the following conclusions. Alloy $800 \mathrm{H}$ experienced the most significant changes in the microstructure, dominated by irradiation induced precipitates. The irradiation induced precipitation (and projected hardening) is much worse at $800^{\circ} \mathrm{C}$ than at $500^{\circ} \mathrm{C}$. The significant microstructural changes material should not be considered to be used in irradiation environments at high temperature, particularly at $800^{\circ} \mathrm{C}$. No significant changes are identified in both ODS alloys, MA754 and MA957, on the irradiated microstructure. The oxide dispersion particles remain stable under the irradiation conditions investigated. Austenitic ODS alloy MA754 is anticipated to develop void swelling due to its high Ni content, therefore it should not be considered for high irradiation field application. Two ferritic alloys, ODS MA957 and HCM12A, showed no significant changes in the irradiated microstructure. Both are good candidate materials to be used for GNEP cladding program. However, ferritic ODS alloy should only be considered if an upper temperature limit higher than that for HCM12A $\left(\sim 620^{\circ} \mathrm{C}\right)$ becomes necessary. The future work on the high dose ( $>10 \mathrm{dpa}$ ) irradiation of the same set of alloys will provide valuable information to a better understanding of the microstructural performance under neutron irradiation. 

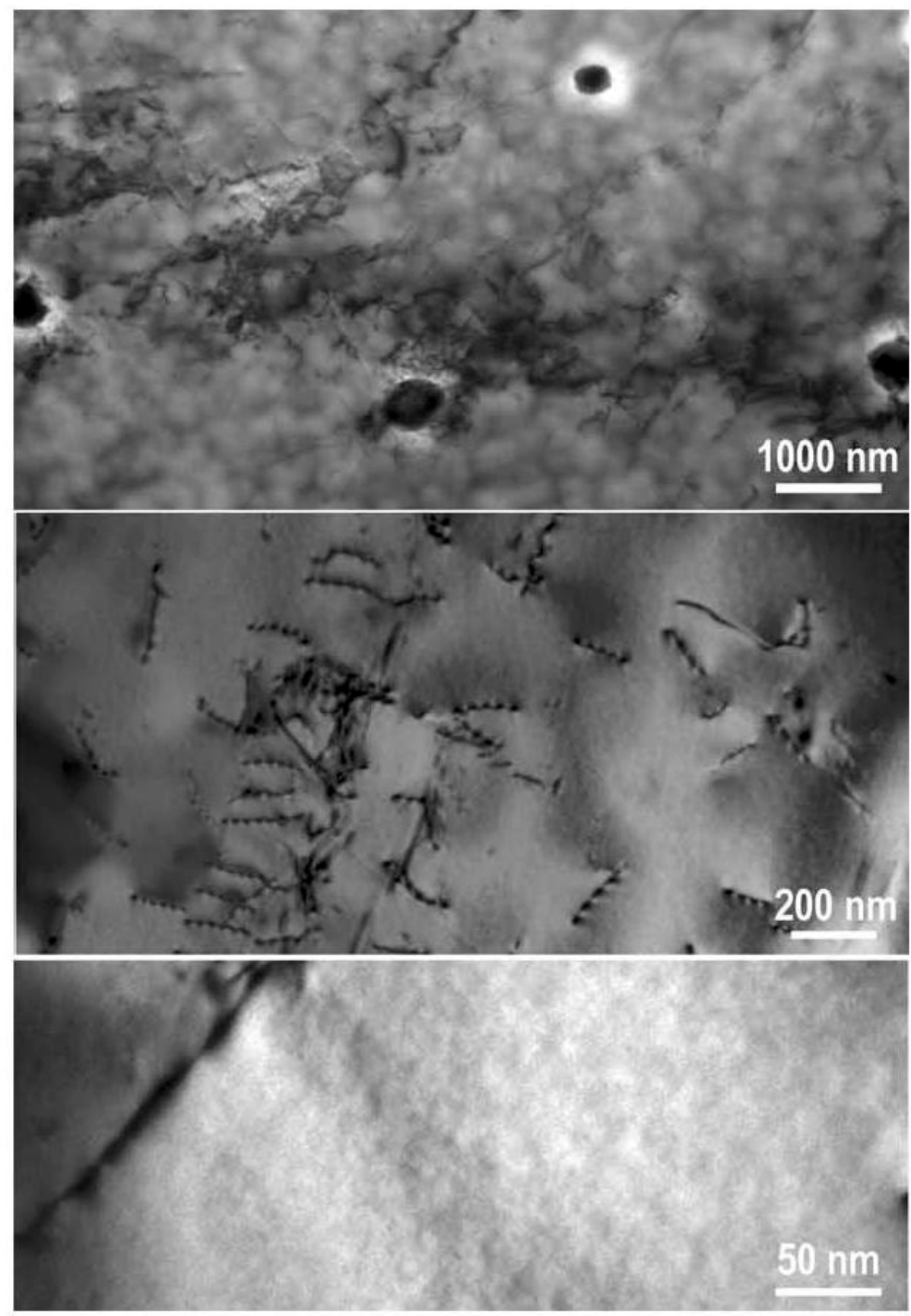

Figure 1. Unirradiated microstructure of alloy $800 \mathrm{H}$ (imaged with $\mathrm{g}=200$ diffraction) reveals large and scattered Ti rich particles (top), dislocations in low magnification (middle), and high magnification (bottom). 


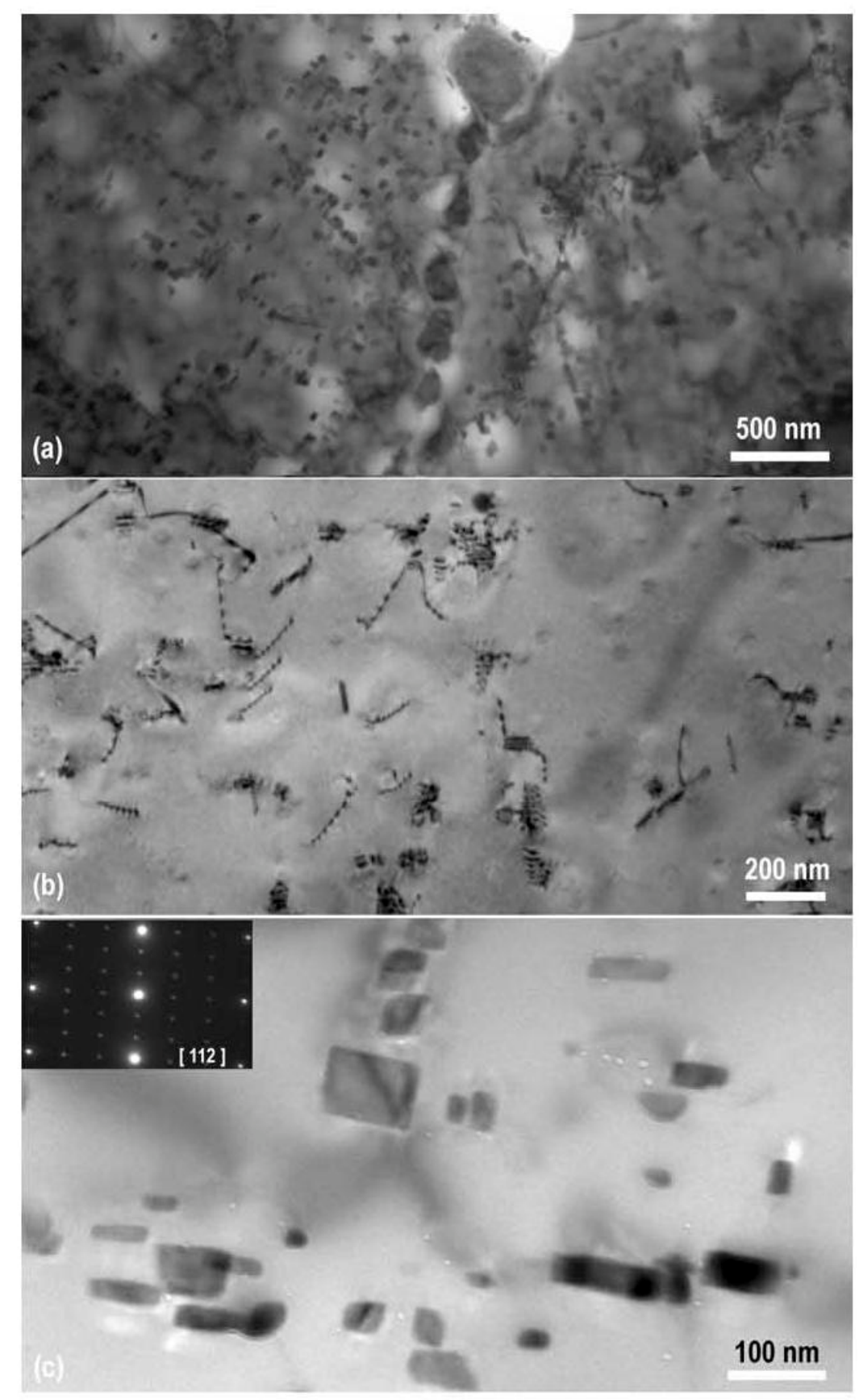

Figure 2. Bright field images showing defect features in the alloy $800 \mathrm{H}$ irradiated with neutrons at $500^{\circ} \mathrm{C}$ to 1.3 dpa. (a) distribution of $\mathrm{M}_{23} \mathrm{C}_{6}$ precipitates with small ones in the matrix and the large ones at the grain boundaries, (b) dislocations and the circular $\gamma^{\prime}$ precipitates in the weak contrast, and (c) the high magnification view of the faceted feature of $\mathrm{M}_{23} \mathrm{C}_{6}$ precipitates and micro voids $(<5 \mathrm{~nm})$ in the white contrast. 

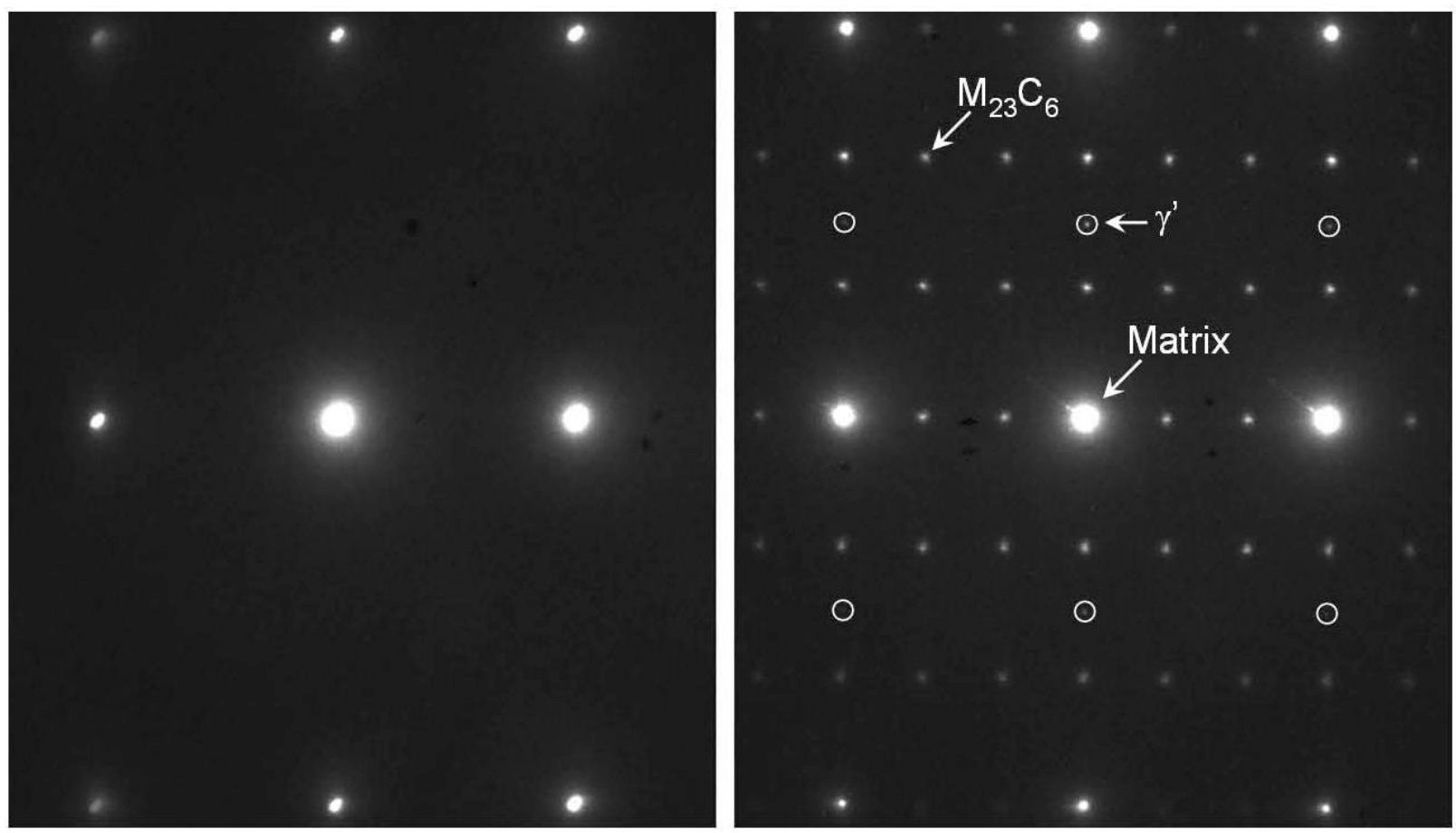

Figure 3. Comparison of $<112>$ zone diffraction in alloy $800 \mathrm{H}$ between the unirradiated (left) and the neutron-irradiated at $500^{\circ} \mathrm{C}$ to $1.3 \mathrm{dpa}$ (right). Two types of coherent precipitates are found in the irradiated alloy, and the circles mark the weak spots due to $\gamma^{\prime}$ precipitates. 


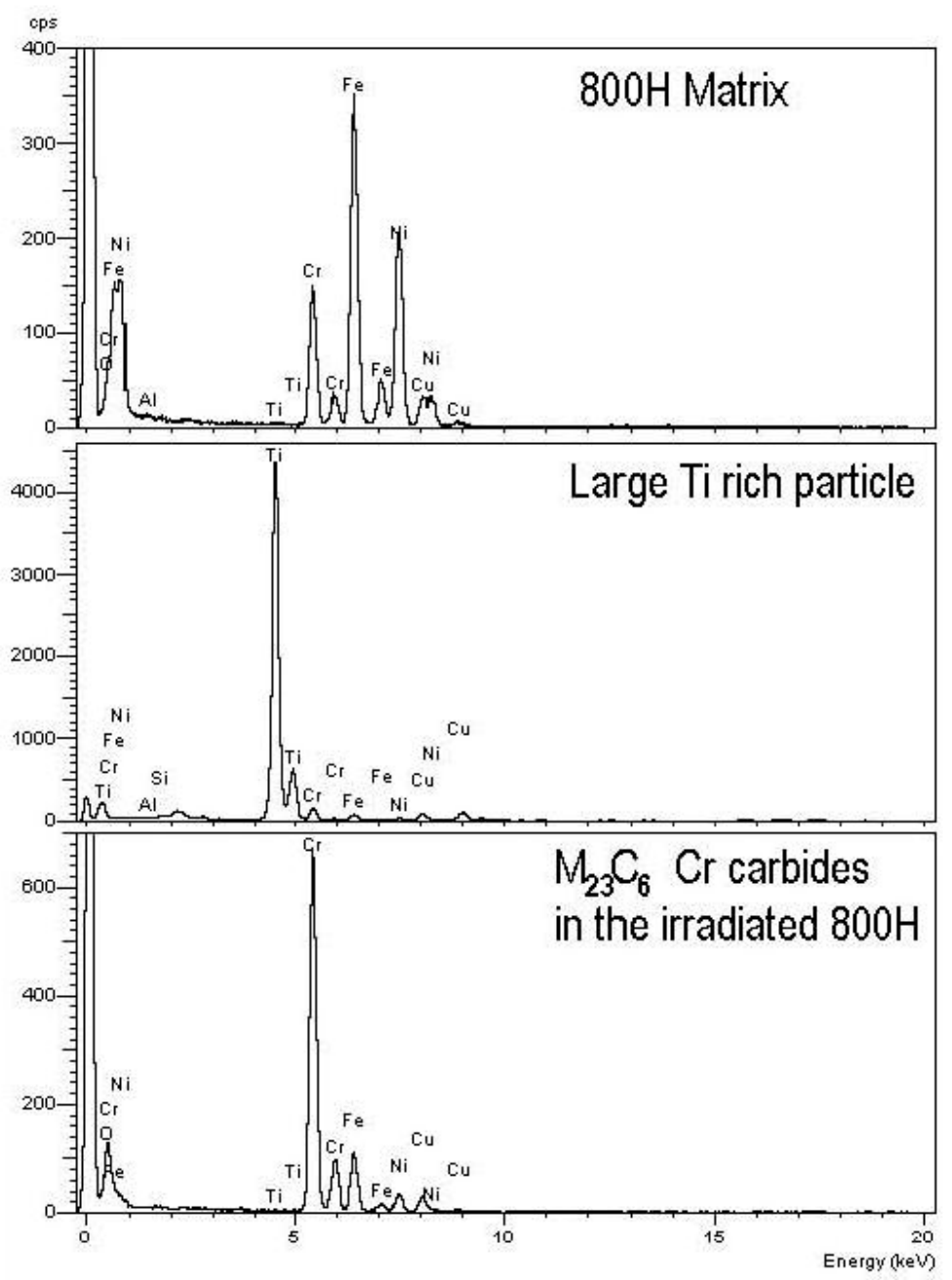

Figure 4. EDS plots of alloy $800 \mathrm{H}$ for the matrix (top), the large Ti-rich particles existed in both the unirradiated and the irradiated condition (middle), and the $\mathrm{M}_{23} \mathrm{C}_{6}$ precipitates in the irradiated condition (bottom). EDS measurement of irradiation-induced $\gamma^{\prime}$ precipitates is not quantifiable due to their small size. 


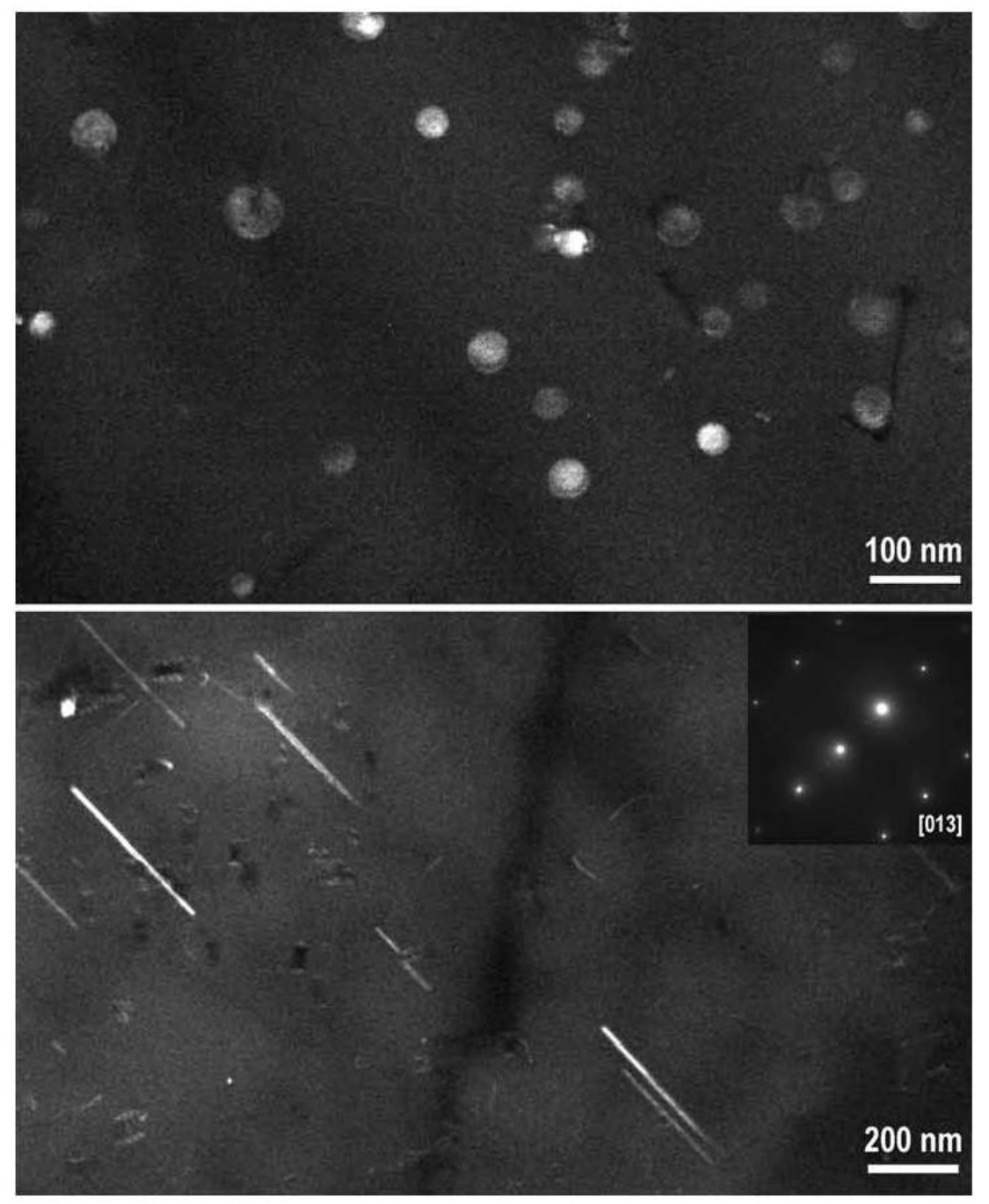

Figure 5. Weak beam dark field images showing the circular $\gamma^{\prime}$ precipitates (top) and the thin plate features (bottom) in the alloy $800 \mathrm{H}$ irradiated with neutrons at $500^{\circ} \mathrm{C}$ to $1.3 \mathrm{dpa}$. 


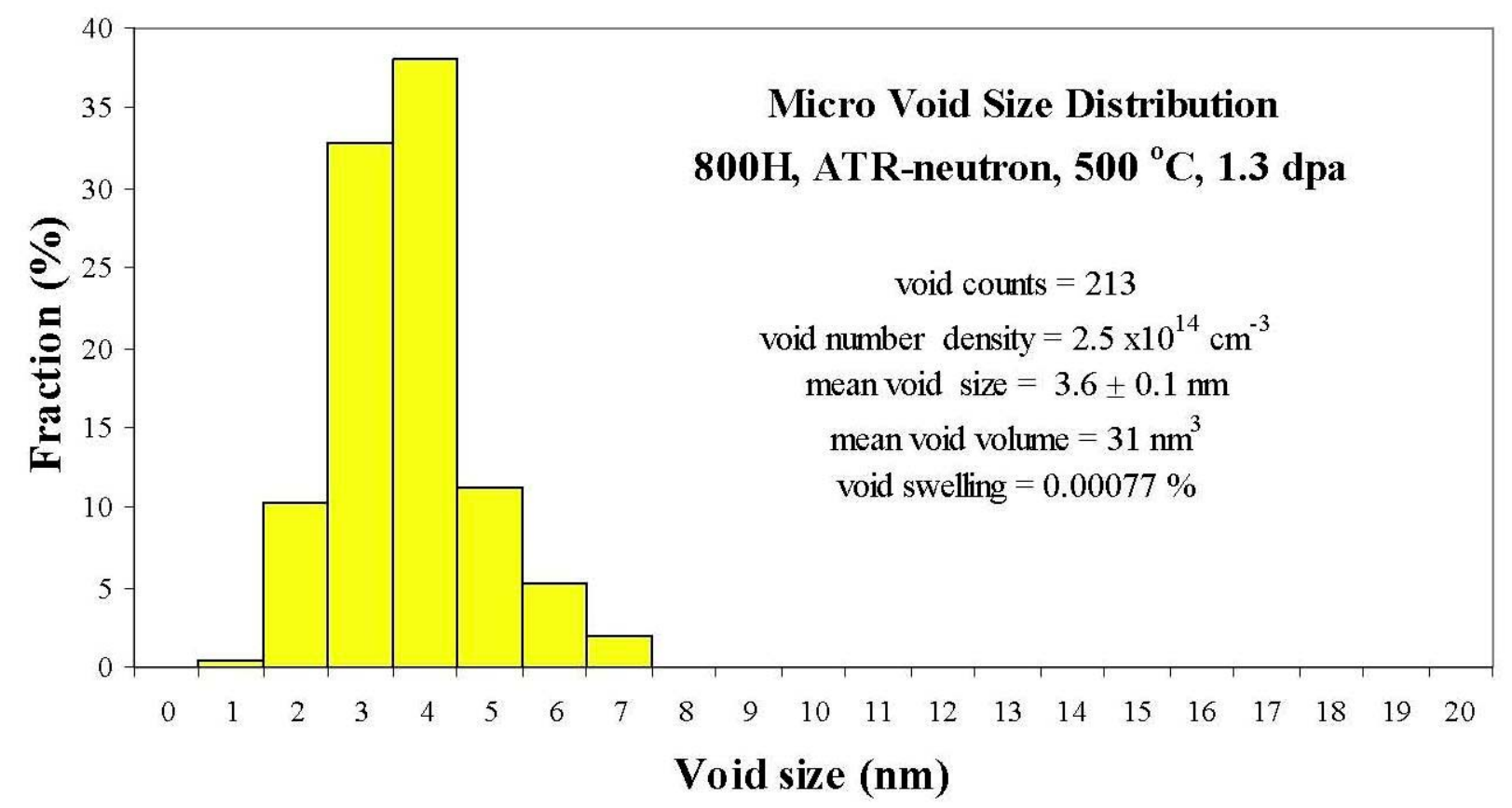

Figure 6. Size distribution of micro voids in the alloy $800 \mathrm{H}$ irradiated at $500^{\circ} \mathrm{C}$ to $1.3 \mathrm{dpa}$. Note that the corresponding swelling and hardening are expected to be negligible.
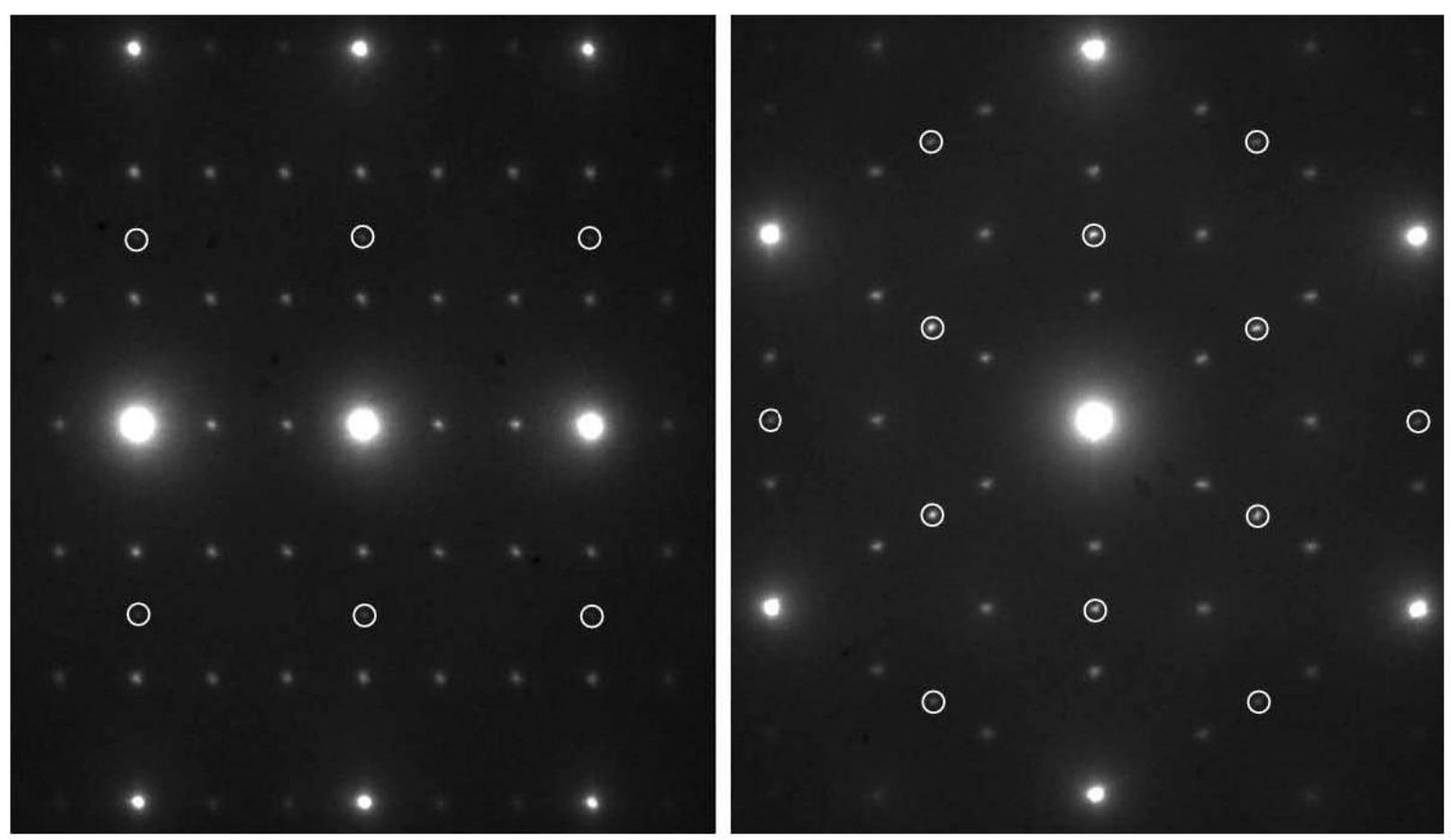

Figure 7. Selected area diffractions of zone $<112>$ (left) and zone $<111>$ (right) for alloy $800 \mathrm{H}$ irradiated with neutrons at $800^{\circ} \mathrm{C}$ to $1.5 \mathrm{dpa}$. There are two types of coherent precipitates found in the irradiated alloy; the circles mark the weak spots due to $\gamma^{\prime}$ precipitates, while the rest of the weak spots are due to $\mathrm{M}_{23} \mathrm{C}_{6}$ precipitates. 


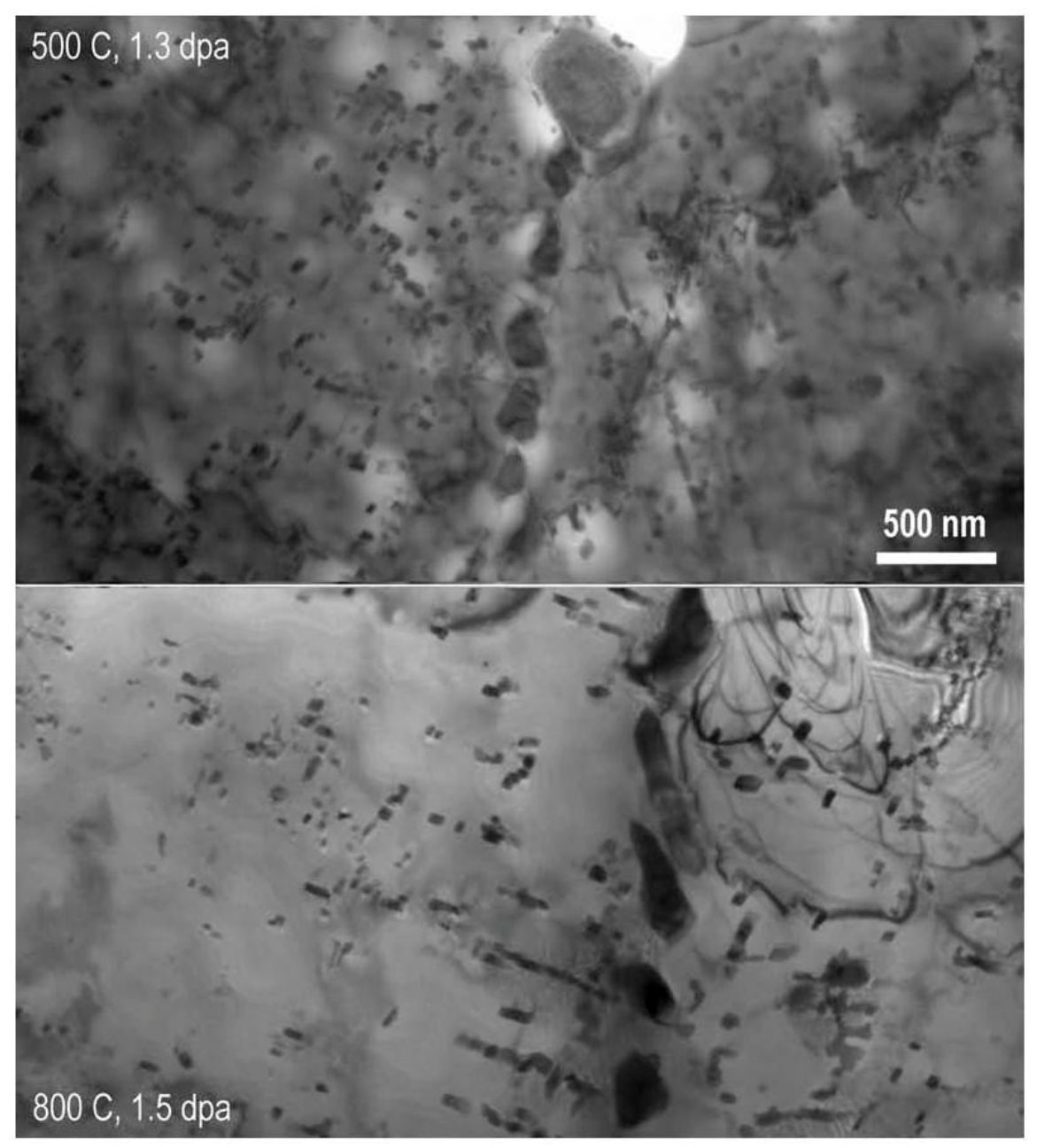

Figure 8. Bright field images showing comparison of irradiation-induced $\mathrm{M}_{23} \mathrm{C}_{6}$ precipitates in the alloy $800 \mathrm{H}$ irradiated with neutrons at $500^{\circ} \mathrm{C}$ to $1.3 \mathrm{dpa}$ (top) and $800^{\circ} \mathrm{C}$ to $1.5 \mathrm{dpa}$ (bottom). Note that the precipitates at the grain boundaries are larger for the irradiation at $800^{\circ} \mathrm{C}$. 


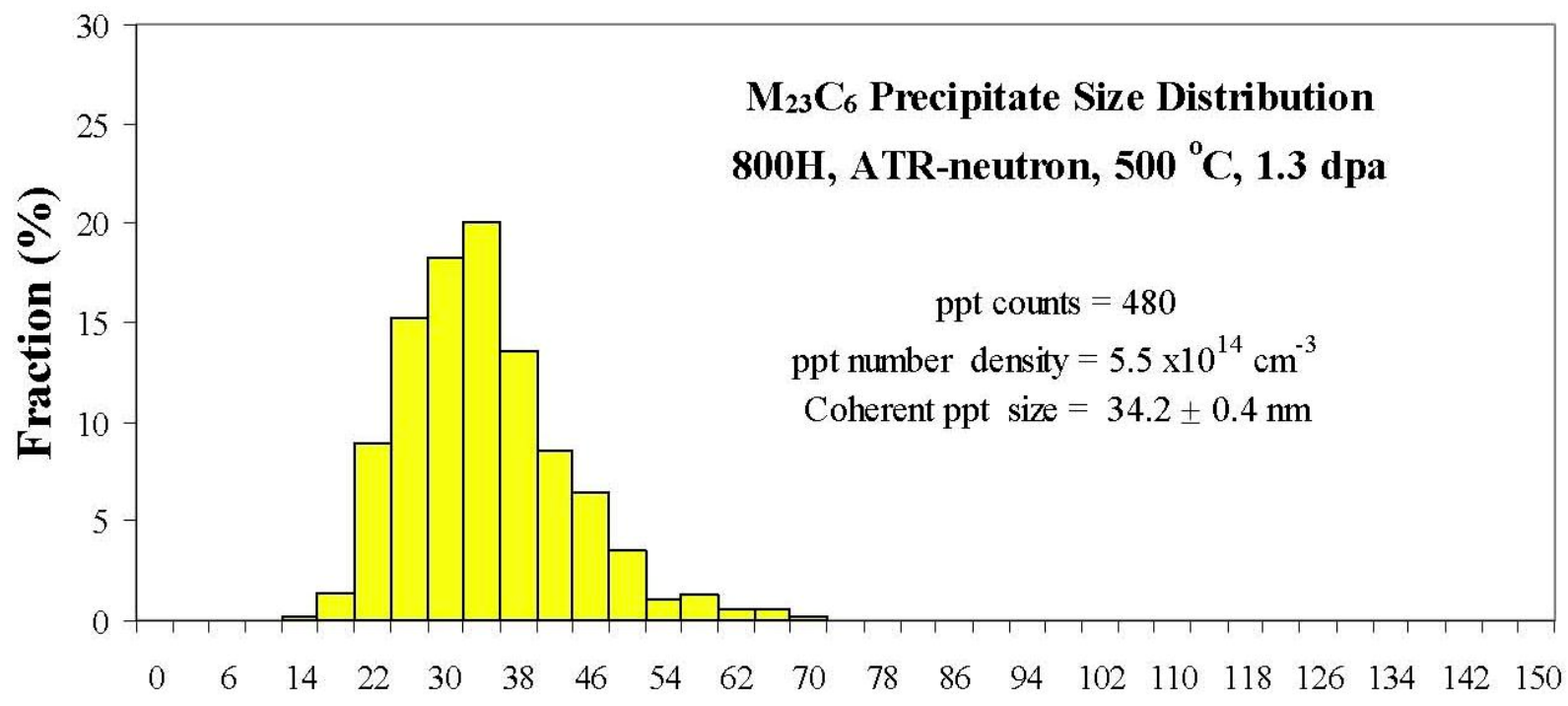

Carbide Precipitate Size (nm)

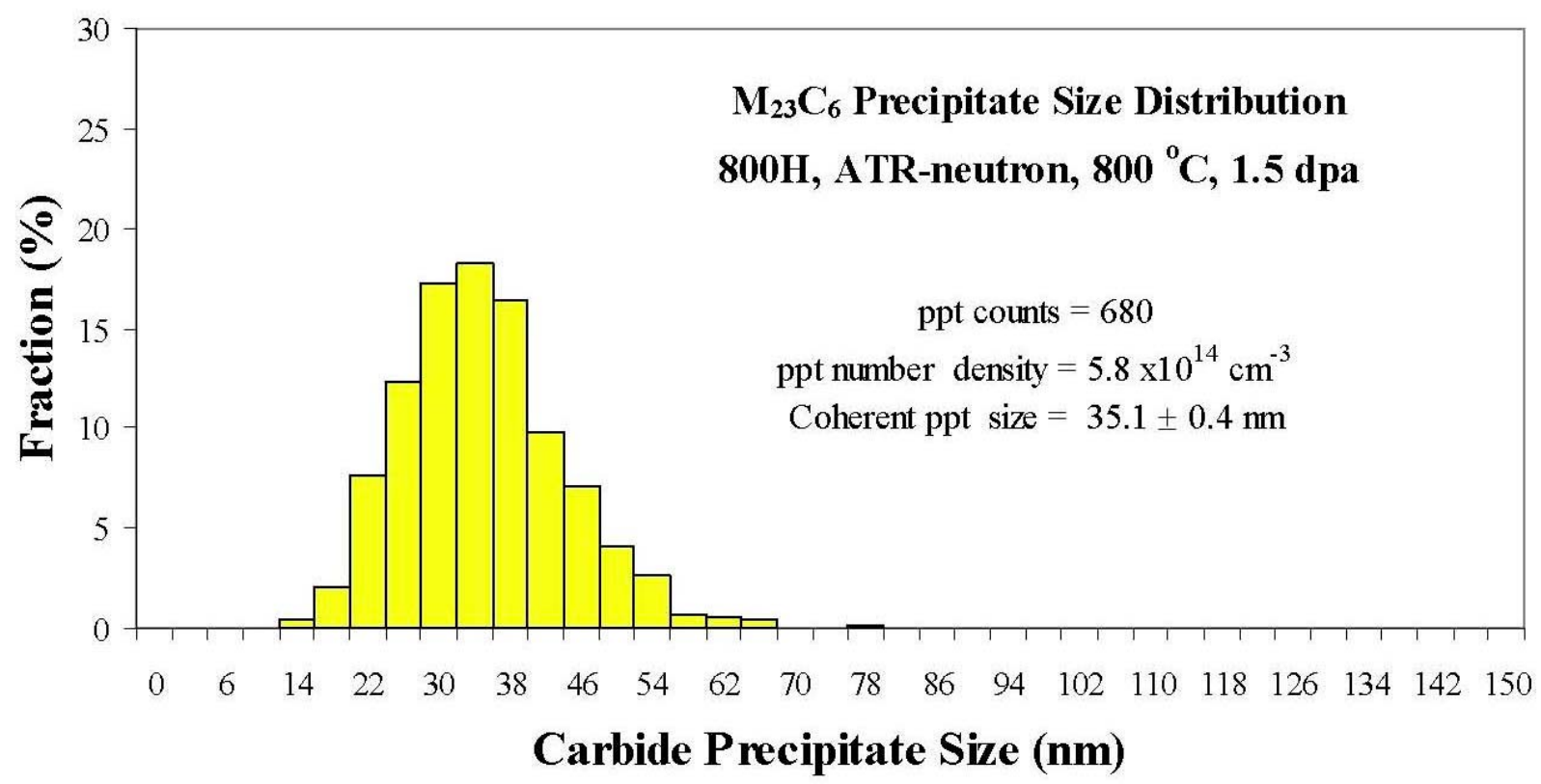

Figure 9. Comparison of size distributions for the irradiation-induced $\mathrm{M}_{23} \mathrm{C}_{6}$ precipitates in the alloy $800 \mathrm{H}$ irradiated with neutrons at $500^{\circ} \mathrm{C}$ to $1.3 \mathrm{dpa}$ (top) and $800^{\circ} \mathrm{C}$ to $1.5 \mathrm{dpa}$ (bottom). There is no significant change on $\mathrm{M}_{23} \mathrm{C}_{6}$ precipitates between the two irradiation conditions. 

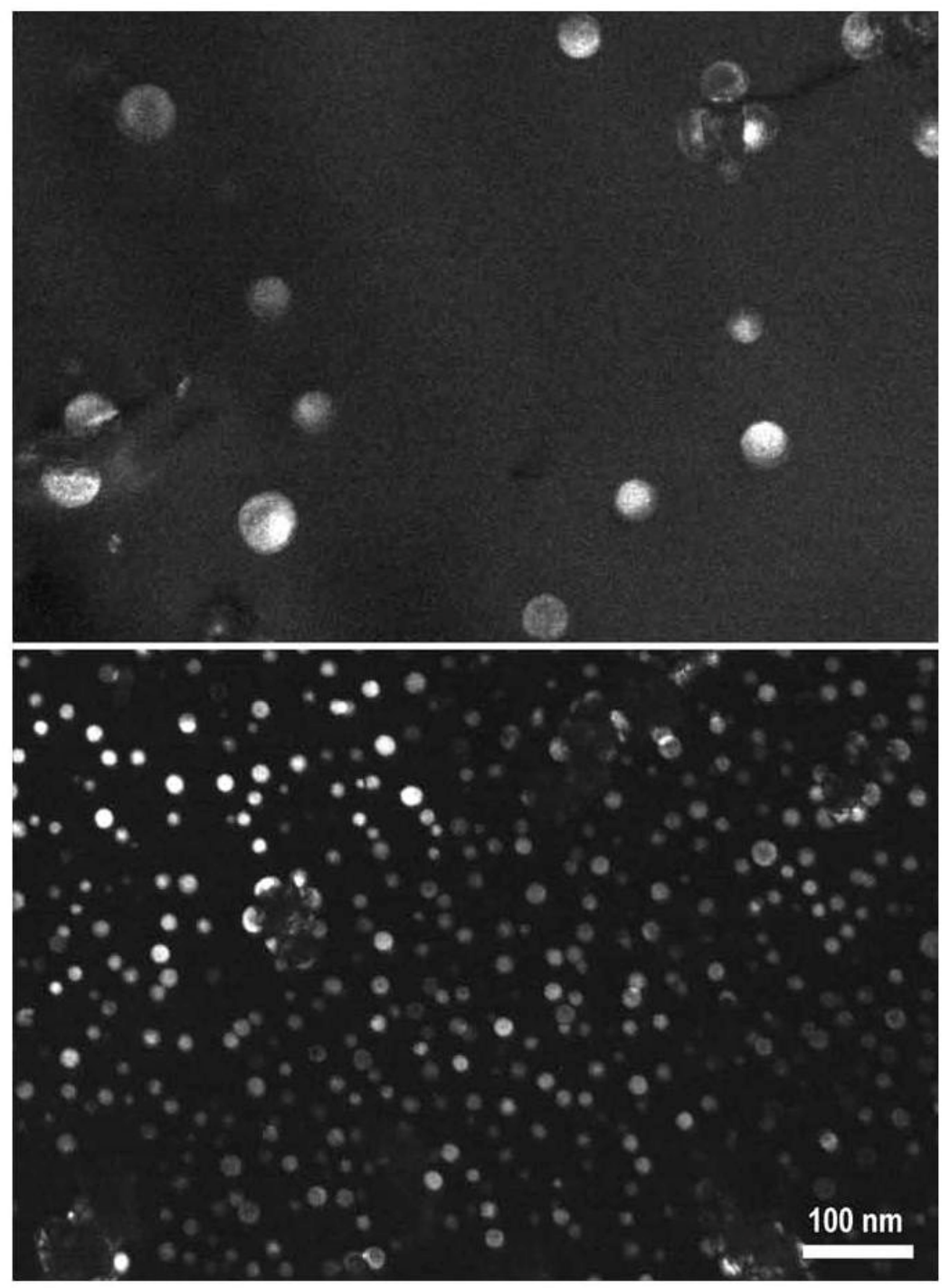

Figure 10. Weak beam dark field images comparing irradiation-induced $\gamma^{\prime}$ precipitates in the alloy $800 \mathrm{H}$ irradiated with neutrons at $500^{\circ} \mathrm{C}$ to $1.3 \mathrm{dpa}$ (top) and $800^{\circ} \mathrm{C}$ to $1.5 \mathrm{dpa}$ (bottom). 

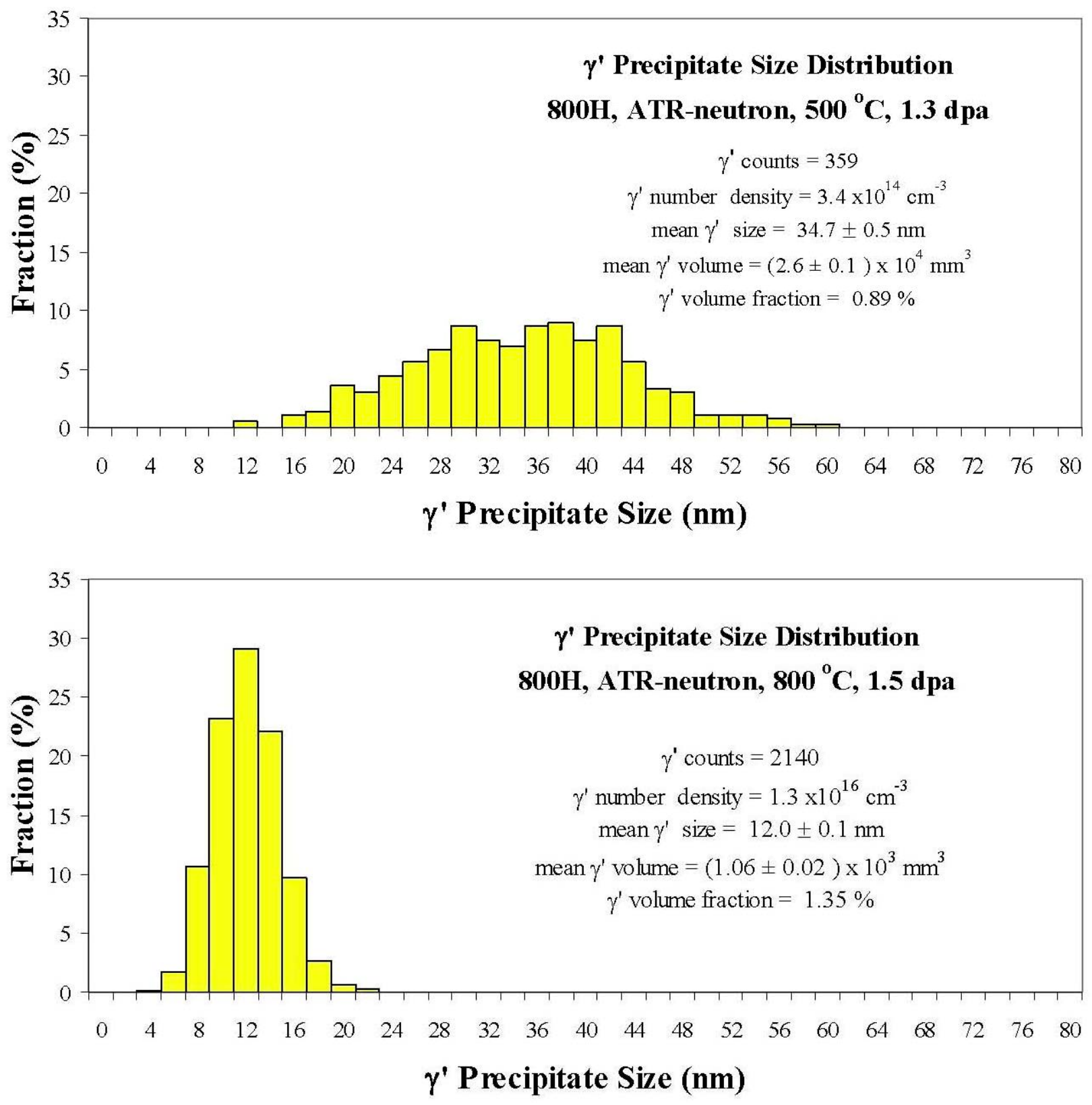

Figure 11. Comparison of size distributions for the irradiation-induced $\gamma^{\prime}$ precipitates in the alloy $800 \mathrm{H}$ irradiated with neutrons at $500^{\circ} \mathrm{C}$ to $1.3 \mathrm{dpa}$ (top) and $800^{\circ} \mathrm{C}$ to $1.5 \mathrm{dpa}$ (bottom). There is a significant change on the size and number density of $\gamma^{\prime}$ precipitates. 

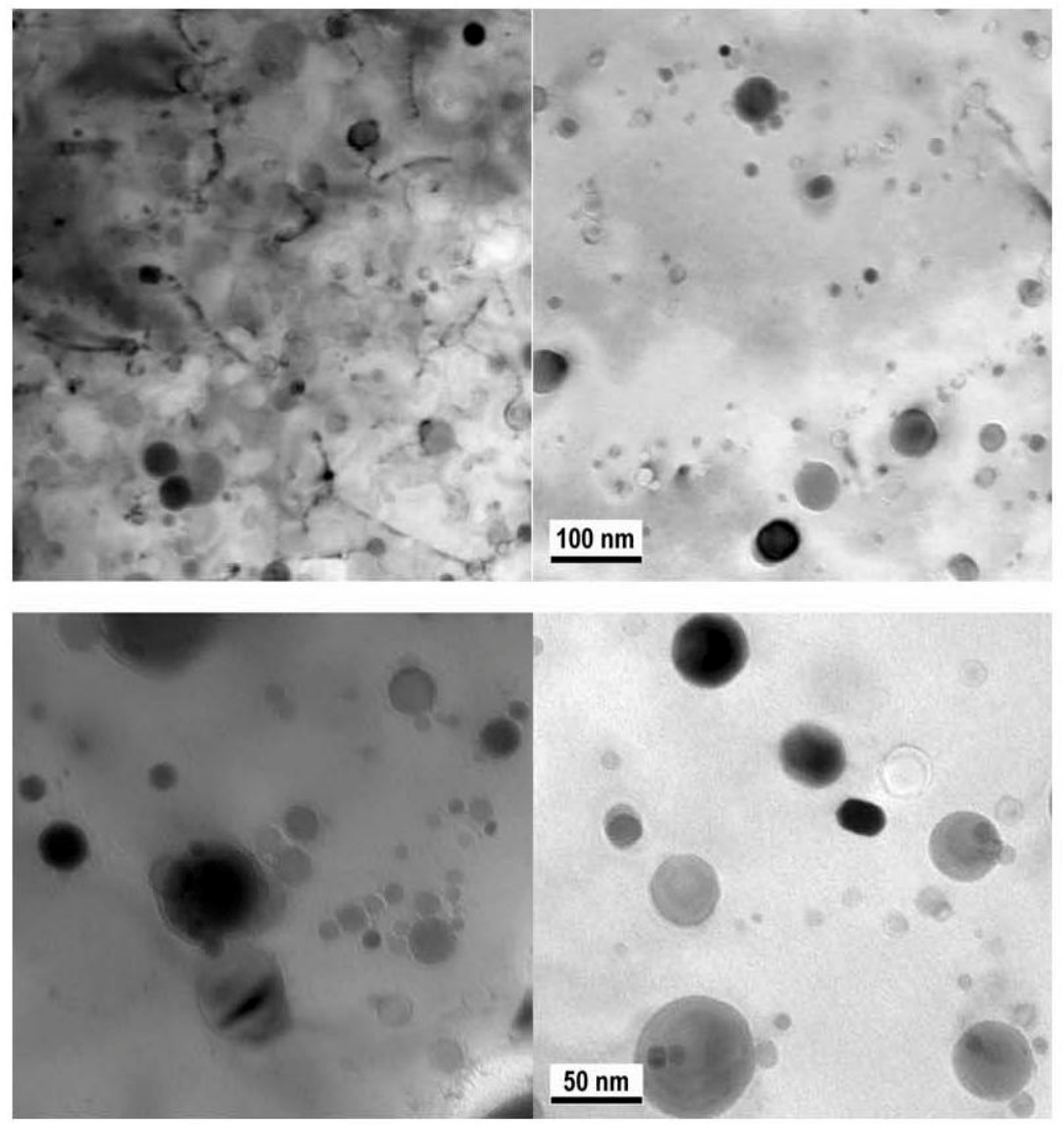

Figure 12. Yttrium oxide particles in alloy MA754 for the unirradiated (left) and the irradiated with neutrons at $500^{\circ} \mathrm{C}$ to $1.2 \mathrm{dpa}$ (right). The images on the top show dislocation contrast using $\mathrm{g}=200$, and the images on the bottom show irradiation effect on yttrium oxides. Dislocation density in the irradiated MA754 is significantly lower, while the irradiation effect on yttrium oxide is not significant. 

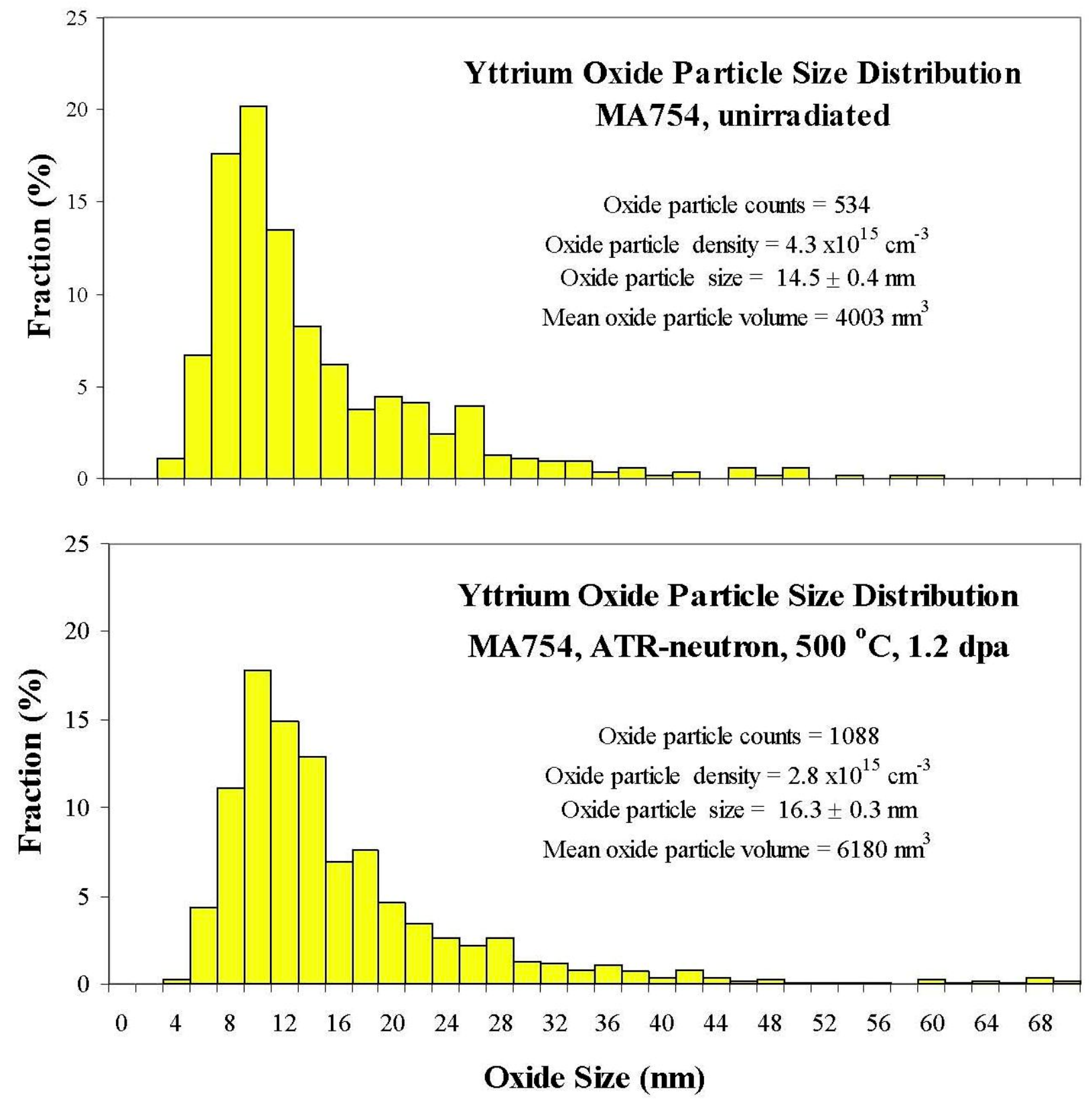

Figure 13. Size distribution of yttrium oxide particles in alloy MA754 for the unirradiated (top) and the irradiated with neutrons at $500^{\circ} \mathrm{C}$ to $1.2 \mathrm{dpa}$ (bottom). There is no significant change in average size, size distribution, and number density of the oxide particles. 

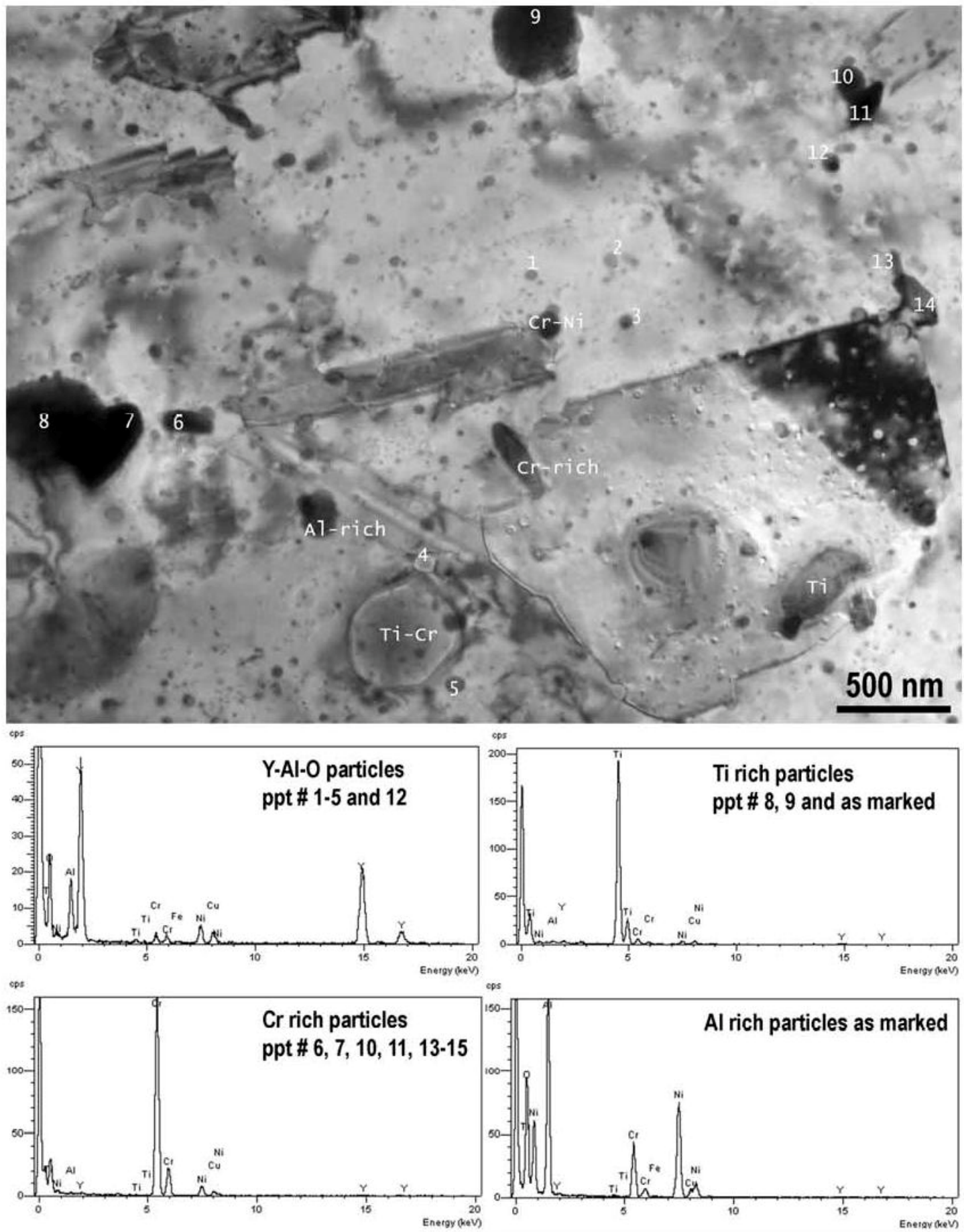

Figure 14. Various precipitates found in both the unirradiated and the irradiated alloy MA754 (at $500^{\circ} \mathrm{C}$ to $1.2 \mathrm{dpa}$ ). The plots show the EDS measurement for the major precipitates identified in the alloy. 

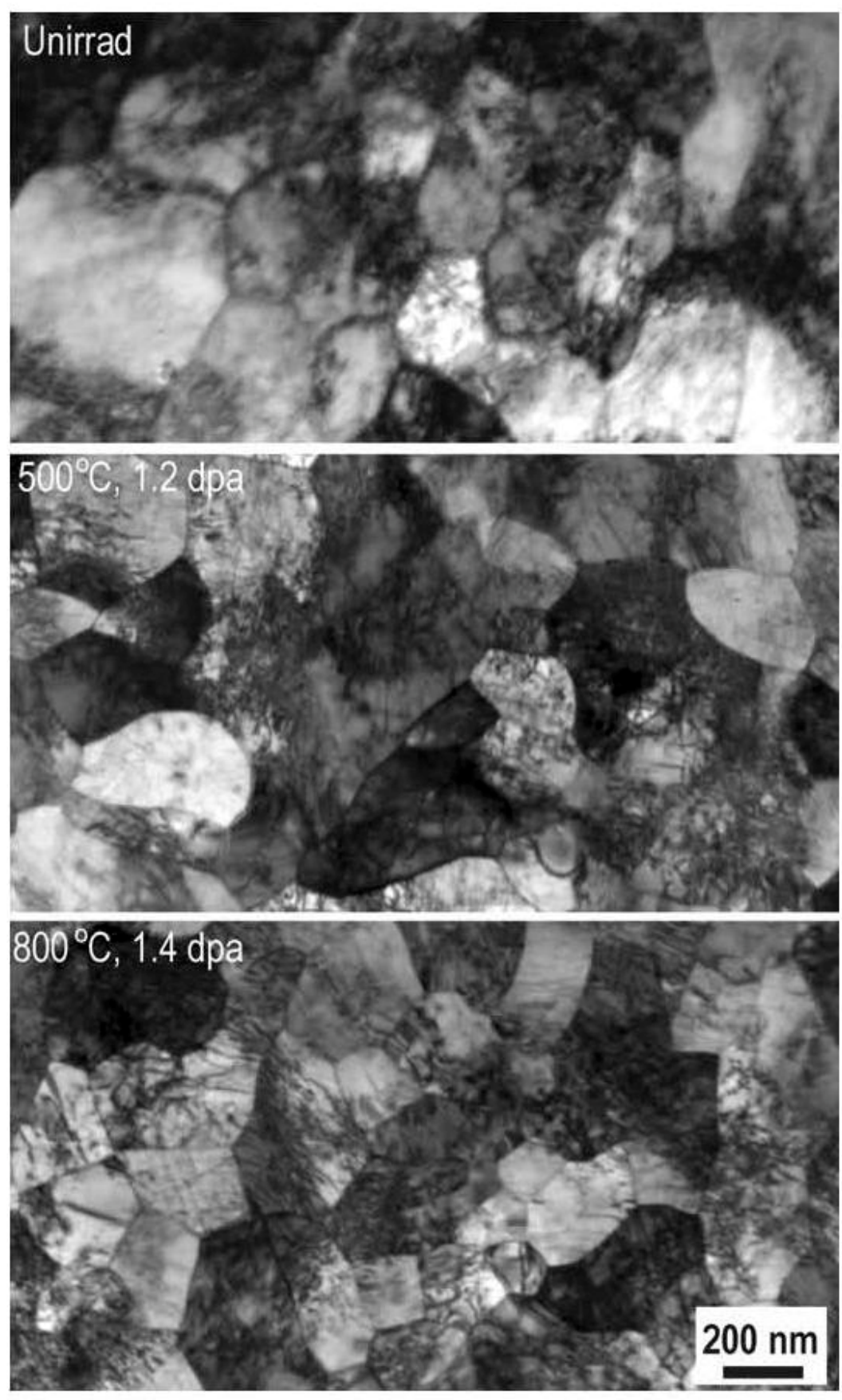

Figure 15. Low magnification images of microstructural features in MA957 for the unirradiated (top), the irradiated at $500^{\circ} \mathrm{C}$ to $1.2 \mathrm{dpa}$ (middle), and at $800^{\circ} \mathrm{C}$ to $1.4 \mathrm{dpa}$ (bottom). No noticeable changes in the general microstructure. 

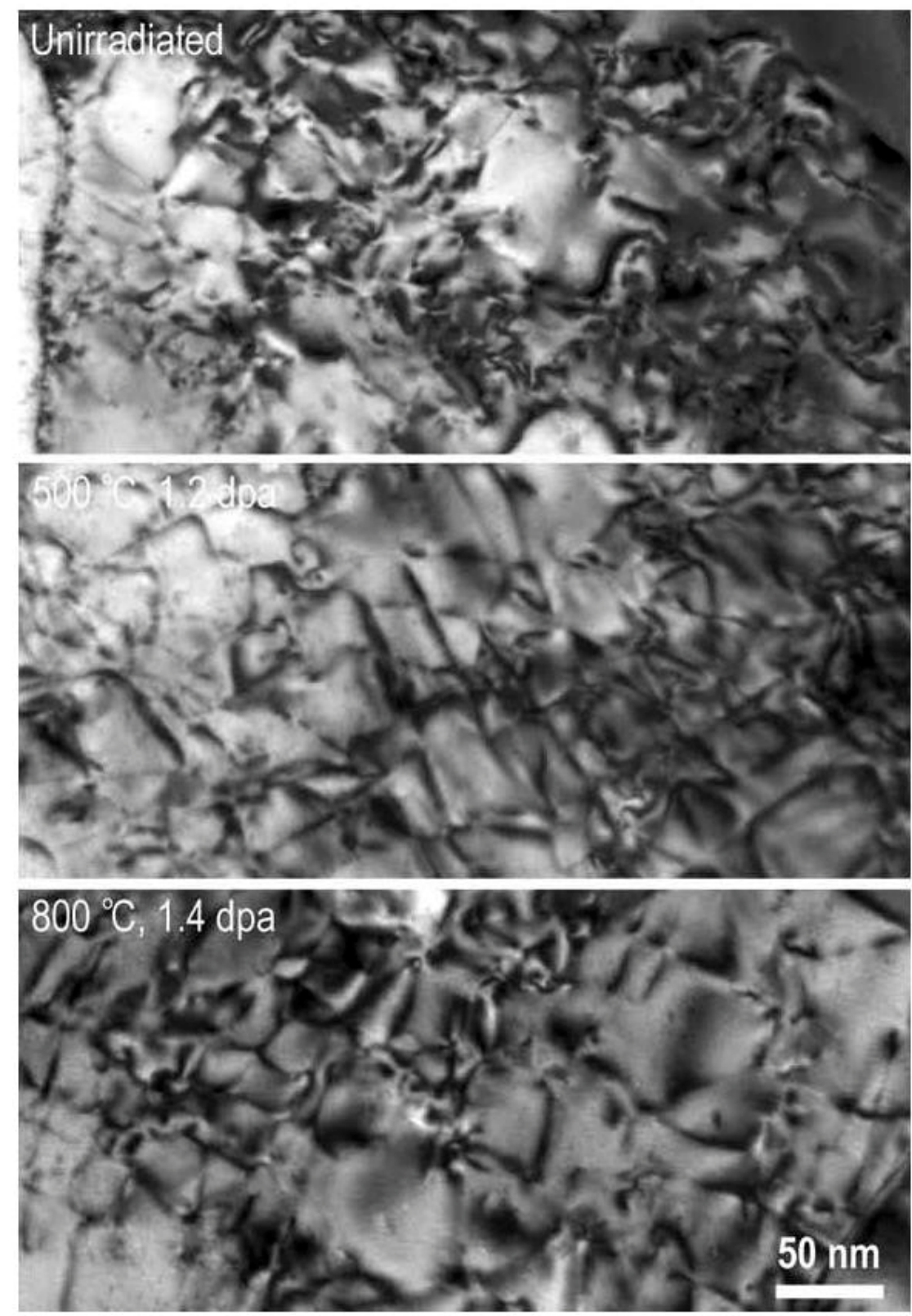

Figure 16. High magnification images of dislocations in MA957 for the unirradiated (top), the irradiated at $500^{\circ} \mathrm{C}$ to $1.2 \mathrm{dpa}$ (middle), and at $800^{\circ} \mathrm{C}$ to $1.4 \mathrm{dpa}$ (bottom). No noticeable changes in the dislocation configuration. 

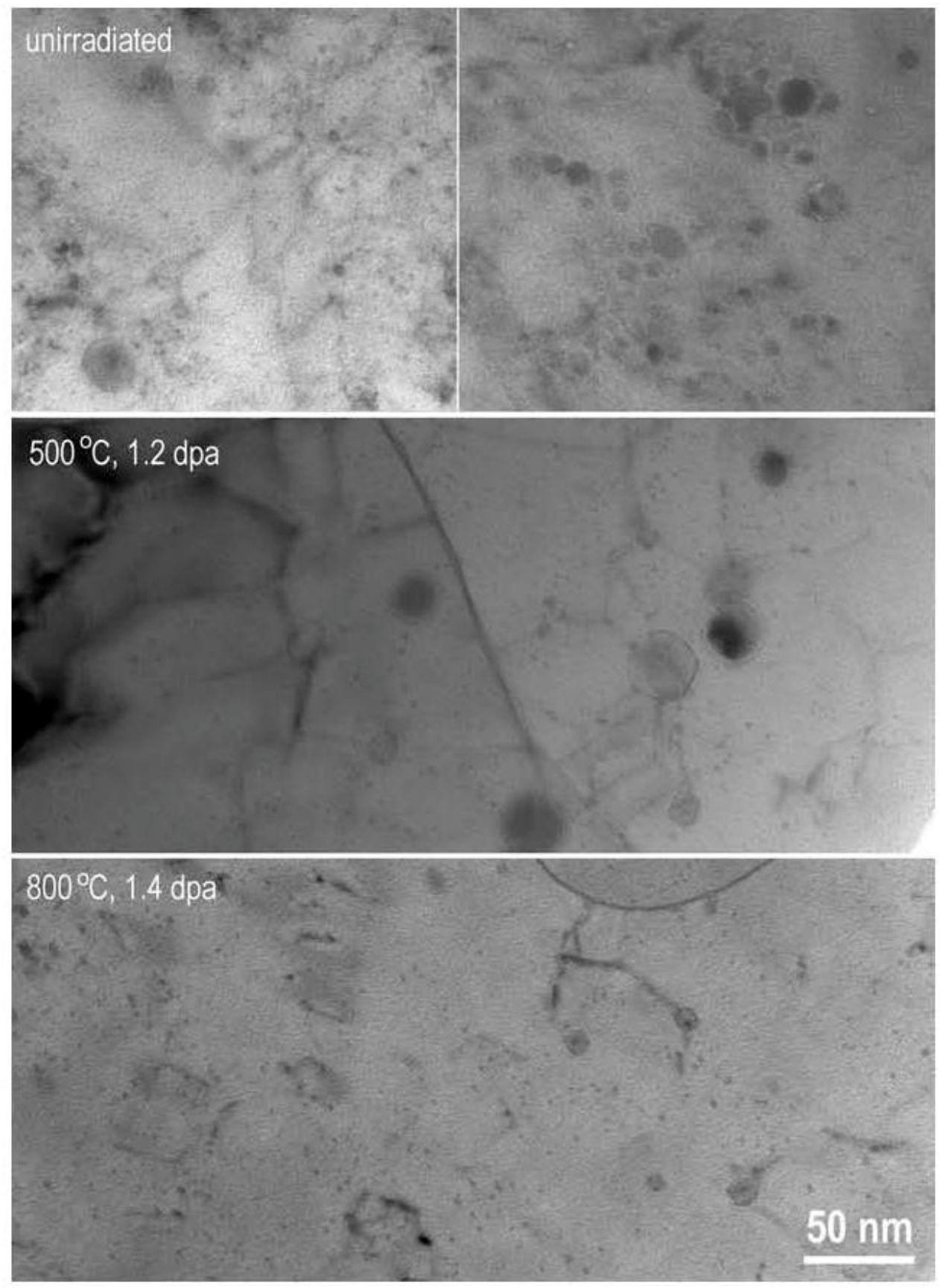

Figure 17. High magnification images of yttrium oxide particles (large circular features and small spots) in MA957 for the unirradiated (top), the irradiated at $500^{\circ} \mathrm{C}$ to $1.2 \mathrm{dpa}$ (middle), and at $800^{\circ} \mathrm{C}$ to $1.4 \mathrm{dpa}$ (bottom). 

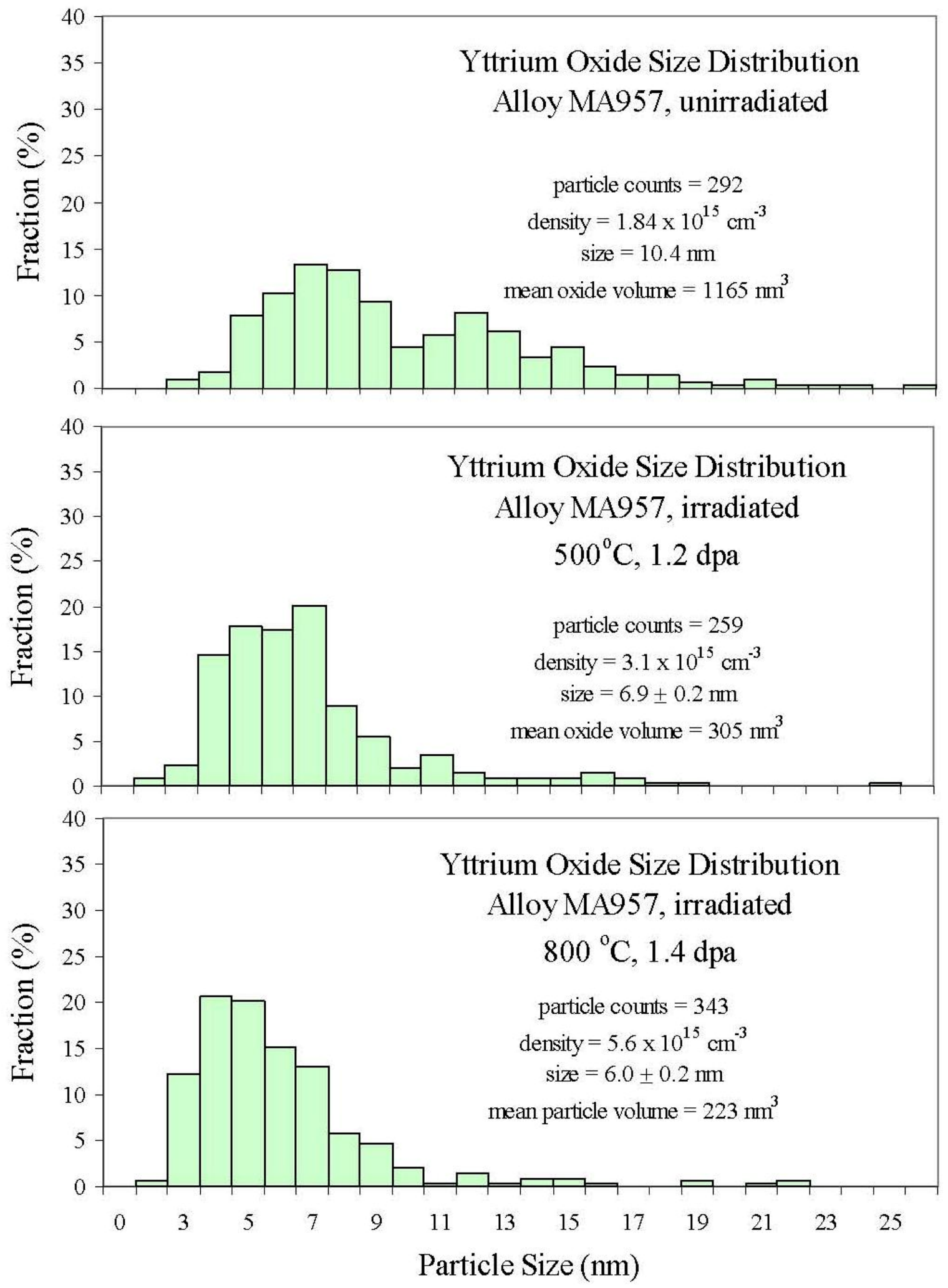

Figure 18. Size distribution of yttrium oxide particles in MA957 for the unirradiated (top), the irradiated at $500^{\circ} \mathrm{C}$ to $1.2 \mathrm{dpa}$ (middle), and at $800^{\circ} \mathrm{C}$ to $1.4 \mathrm{dpa}$ (bottom). Irradiation resulted in smaller average sizes and higher densities of the oxide particles. 

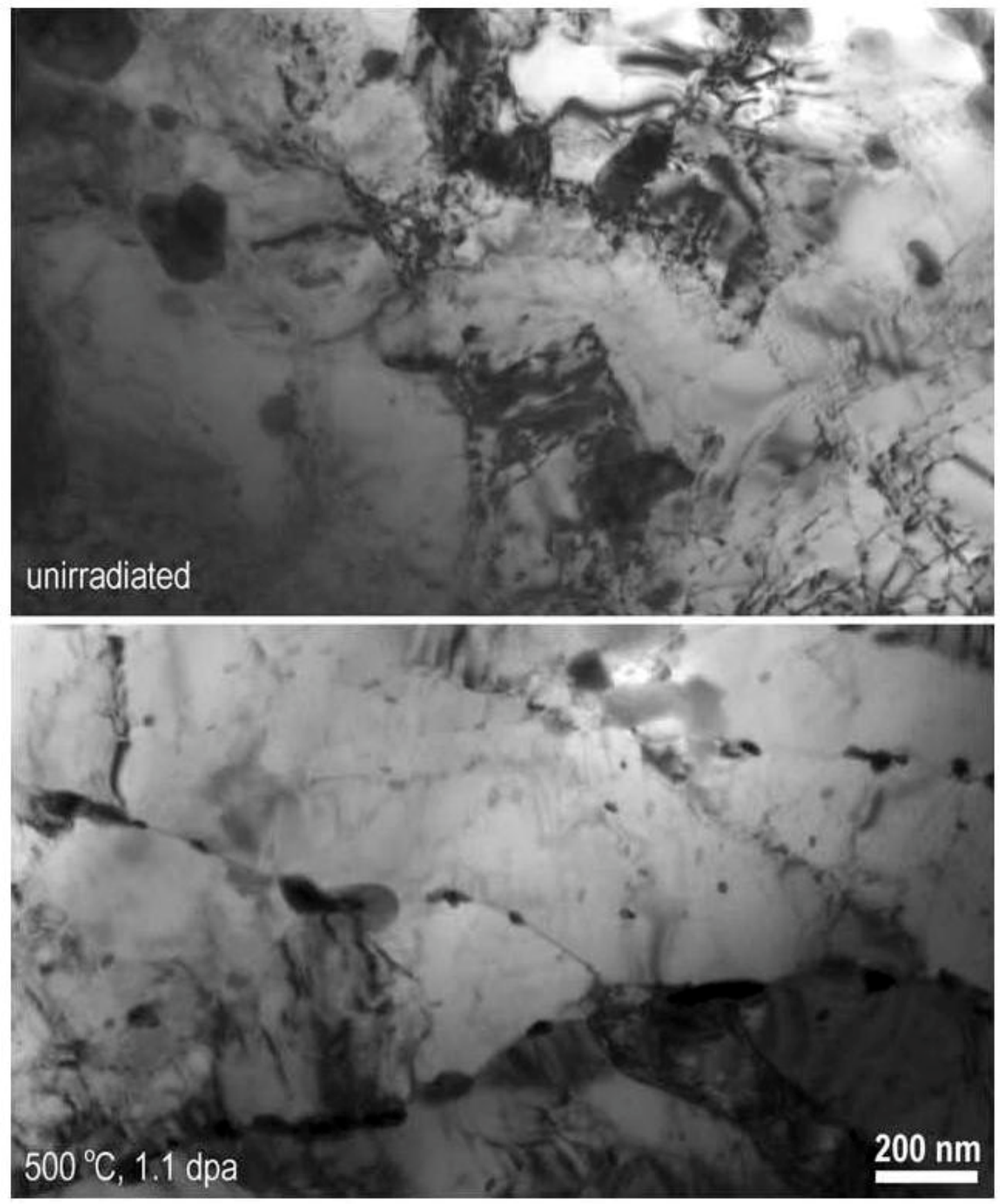

Figure 19. Low magnification images of general microstructural features in HCM12A for the unirradiated (top) and the irradiated at $500^{\circ} \mathrm{C}$ to $1.1 \mathrm{dpa}$ (bottom). 

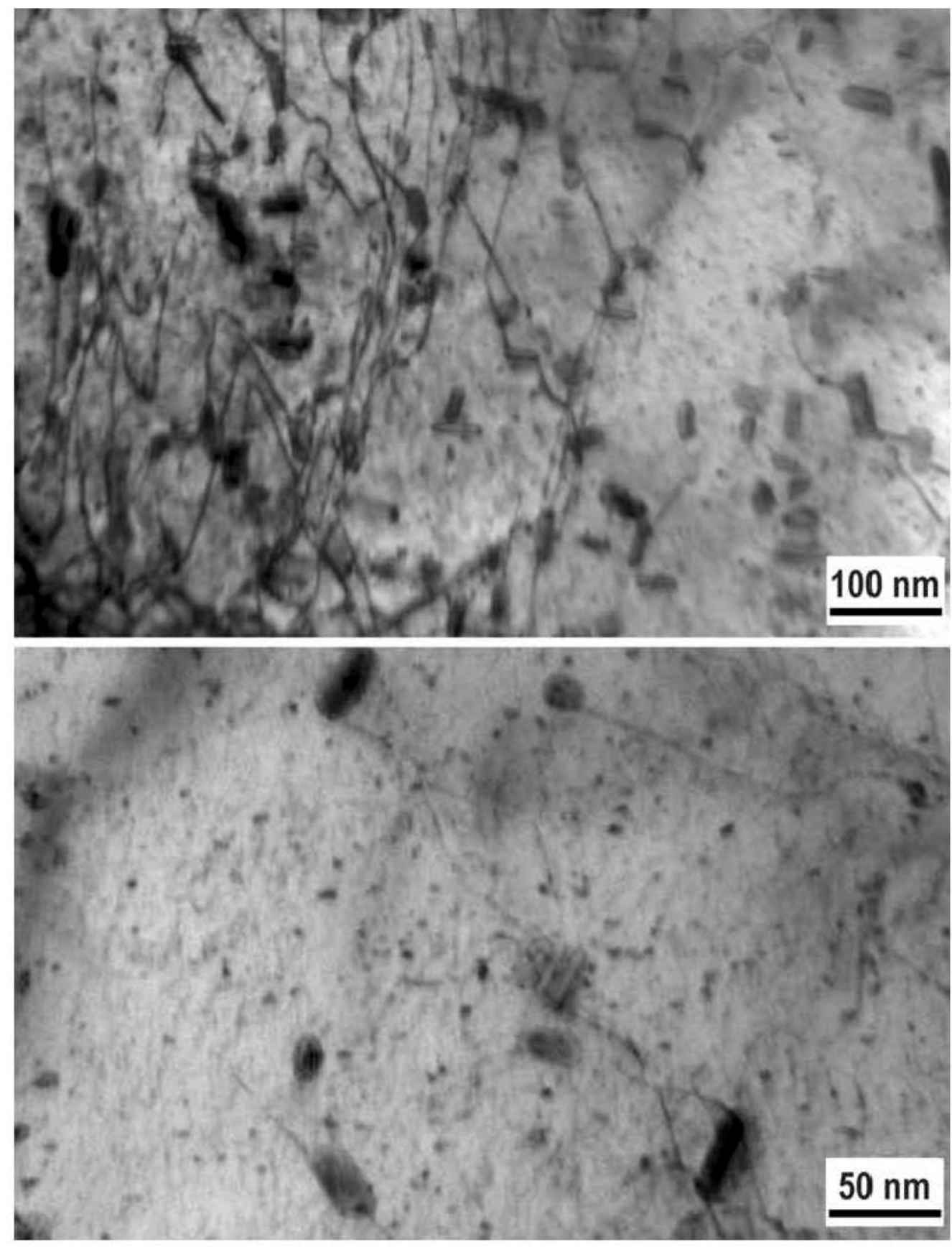

Figure 20. High magnification image showing dislocations ( $\mathrm{g}=1,-1,0)$, precipitates (top) and black dots in $\mathrm{HCM} 12 \mathrm{~A}$ irradiated at $500^{\circ} \mathrm{C}$ to $1.1 \mathrm{dpa}$ (bottom). Few scattered dislocation loops are visible in the image on the top. 


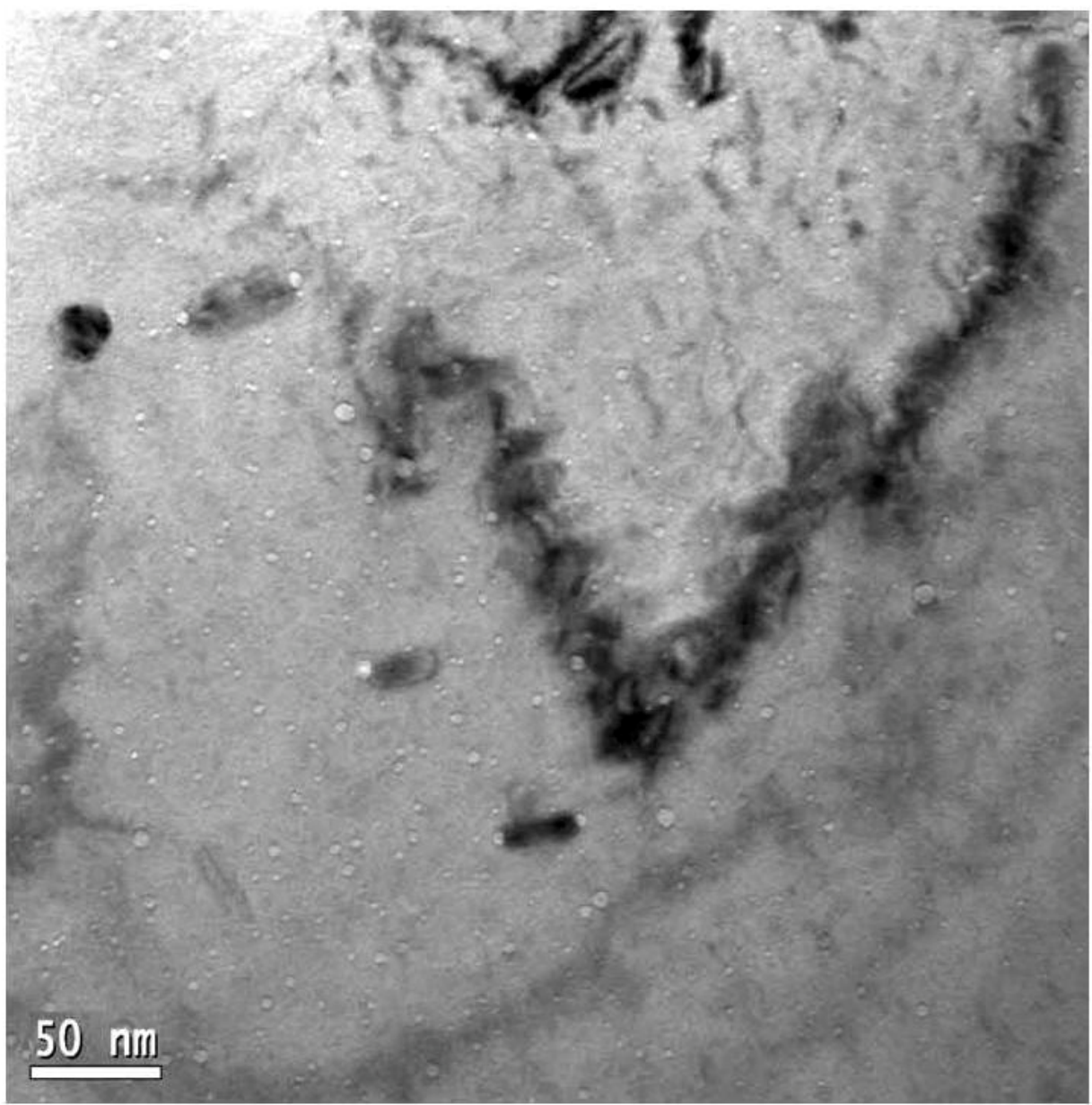

Figure 21. Voids are found in one area $\left(\sim 10 \mu \mathrm{m}^{2}\right)$ of the $\mathrm{HCM} 12 \mathrm{~A}$ alloy irradiated at $500^{\circ} \mathrm{C}$ to $1.1 \mathrm{dpa}$. 


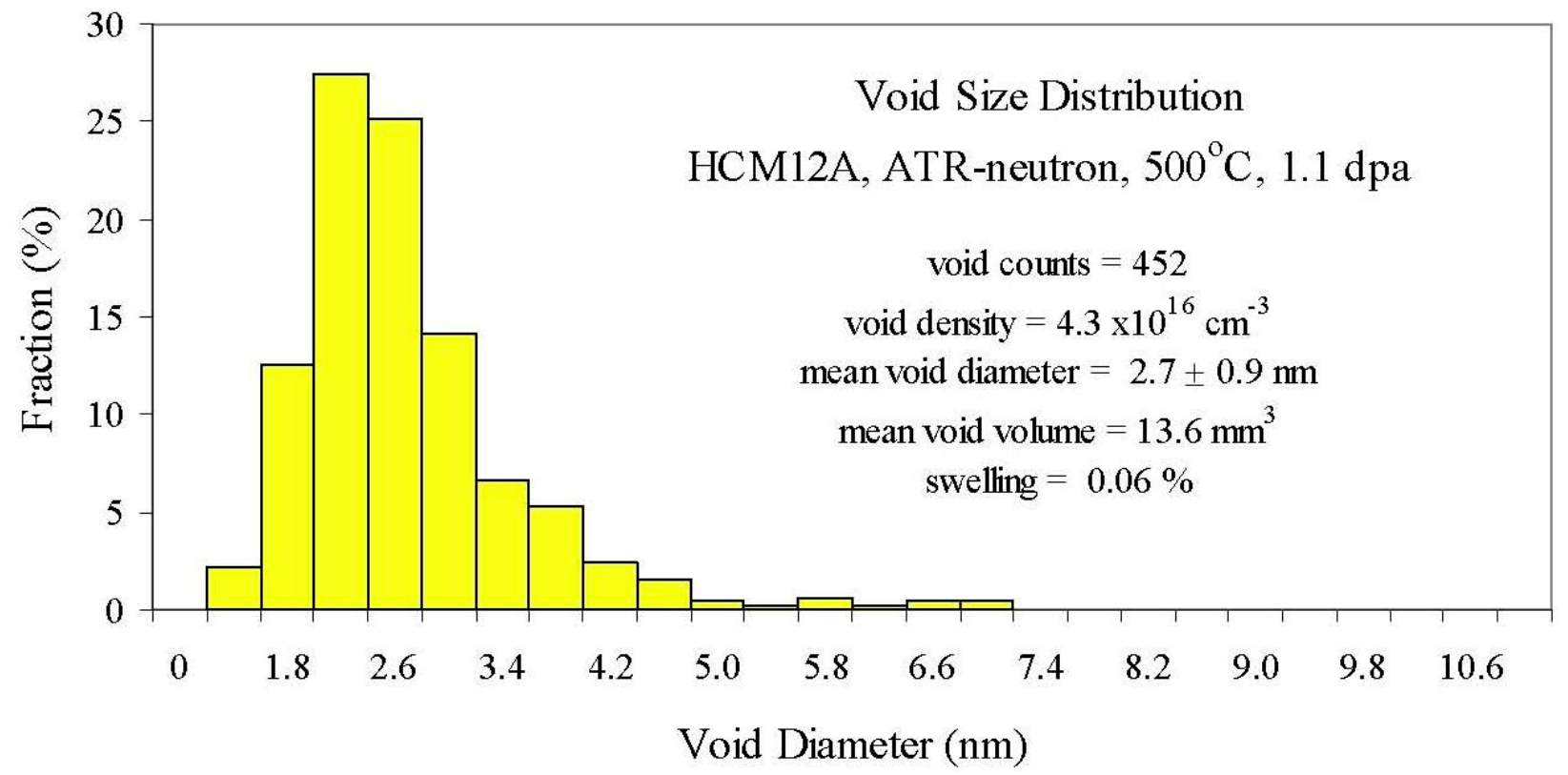

Figure 22. Summary of measurement for voids found in a particular area $\left(\sim 10 \mu \mathrm{m}^{2}\right)$ of the HCM12A alloy irradiated with neutrons at $500^{\circ} \mathrm{C}$ to $1.1 \mathrm{dpa}$. 


\section{REFERENCES}

1. Natesan, K., A. Purohit, S. W. Tam, and C. A. Greene., 2003, "Materials Behavior in HTGR Environments," ANL-02/37 and NUREG/CR-6824.

2. Garner, F. A., and A. S. Kumar, 1987, "Radiation-Induced Changes in Microstructure: $13^{\text {th }}$ International Symposium (Part I)," ASTM STP 955, Eds: F. A, Garner, N. H. Packan, and A.S. Kumar, ASTM, Philadelphia, pg. 289.

3. Harris, D. R., 1981, "Physical Metallurgy of Fe-Cr-Ni austenitic Steels," Proceedings of the InternationalConference on Mechanical Behavior and Applications of Stainless Steels at Elevated Temperature; May 1981, Publisher: The Metals Society, London, pg. 1.

4. Technical Notes of MA754 at www.specialmetals.com.

5. Hamilton, M. L., D. S. Gelles, R. J. Lobsinger, G. D. Johnson, W. F. Brown, M. M. Paxton, A. J. Puigh, C. R. Eiholzer, C. Martinez, and M. A. Blotter, "Fabrication Technological Development of the Oxide Dispersion Strengthened Alloy MA957 for Fast Reactor Application," Pacific Northwest National Laboratory, Report No. PNNL-13168.

6. $\quad$ Leggett, R. D., and L. C. Walters, 1993, Journal of Nuclear Materials, 204 (1993) 23.

7. Viswanathan, R., and W. T. Bakker, 2000, Proceedings of the 2000 International Joint Power Generation Conference, Miami Beach, FL, July, 2000, pg.1.

8. Zinkle, S. J., P. J. Maziasz, and R. E. Stoller, 1993, Journal of Nuclear Materials, 206 (1993) 270.

9. Gan, J., J. I. Cole, T. R. Allen, S. Shutthanandan, and S. Thevuthasan, 2006, Journal of Nuclear Materials, 351 (2006) 223-227.

10. Lucus, G. E., 1993, Journal of Nuclear Materials, 206 (1993) 292.

11. Garner, F. A., 1994, "Irradiation Performance of Cladding and Structural Steels in Liquid Metal Reactors," Vol. 10A, Materials Science and Technology, Edited by R. W. Cahn, P. Haasen, and E. J. Kramer (1994), pg. 420.

12. Shiraishi, H., and A. Hasegawa, 1988, Journal of Nuclear Materials, 155-157 (1988) 1049-1053.

13. Odette, G. R., 1988, Journal of Nuclear Materials, 155-157 (1988) 921-927.

14. Allen, T. R., J. Gan, J. I. Cole, S. Ukai, S. Shutthanandan, and S. Thevuthasan, 2005, "The Stability of 9Cr-ODS Oxide Particles Under Heavy Ion Irradiation," Nuclear Science and Engineering, $151(2005) 305$.

15. Allen, T.R., L. Tan, J. Gan, G. Gupta, G. S. Was, E. A. Kenik, S. Shutthanandan, and S. Thevuthasan, 2006, Journal of Nuclear Materials, 351(1-3) (2006) 174-186. 
16. Kai, J. J., and R. L. Klueh, 1996, Journal of Nuclear Materials, 230 (1996) 116.

17. Gelles, D.S., and A. Kohyama, DOE Report DOE/ER-031316, pg. 193. 